\title{
Debt Contracting and Real Earnings Management
}

Article in SSRN Electronic Journal · May 2011

DOI: $10.2139 /$ ssrn. 1701218

CITATIONS

0

4 authors, including:

Mikhail Pevzner

University of Baltimore

40 PUBLICATIONS 236 CITATIONS

SEE PROFILE
READS

2,022

Some of the authors of this publication are also working on these related projects:

Project Crowdfunding View project

Project GOODWILL IMPAIRMENT-Usage of goodwill impairment by investors View project

All content following this page was uploaded by Mikhail Pevzner on 04 April 2014.

The user has requested enhancement of the downloaded file. All in-text references underlined in blue are added to the original document and are linked to publications on ResearchGate, letting you access and read them immediately. 


\title{
Debt Covenant Slack and Real Earnings Management
}

\author{
Bong Hwan Kim* \\ American University \\ Kogod School of Business \\ 4400 Massachusetts Avenue, NW \\ Washington, DC 20016 \\ bkim@american.edu \\ Ling Lei Lisic \\ George Mason University \\ School of Management \\ 4400 University Drive MS 5F4 \\ Fairfax, VA 22030 \\ 1lisic@gmu.edu \\ Mikhail Pevzner \\ George Mason University \\ School of Management \\ 4400 University Drive MS 5F4 \\ Fairfax, VA 22030 \\ mpevzner@gmu.edu
}

May 2011

\begin{abstract}
*Corresponding author. We thank Rashad Abdel-Khalik, J.K. Aier, Richard Cazier, Dan Cohen, Ed Douthett, Rich Frankel, Keith Jones, Karen Kitching, Dino Silveri, Paul Zarowin, 2011 JAAF/KPMG Foundation Conference participants, 2011 FARS Conference participants, 2011 University of Technology-Sydney Summer Australian Conference participants, and workshop participants at George Mason University for their valuable comments. We also thank Michael Roberts for providing us with the DealscanCompustat matching dataset. Kim thanks Washington University's Olin School of Business' doctoral research program which provided financial and research support in the initial stages of this paper's development. Pevzner thanks the GMU Provost office and the GMU Accounting Area Excellence Fund for financial support of research activities.
\end{abstract}




\title{
Debt covenant slack and real earnings management
}

\begin{abstract}
We examine the relation between firms' real earnings management decisions and the level of slack in their net worth debt covenants. Using private debt covenant data, we find that the overall level of real earnings management is higher when net worth covenant slack is tighter. Moreover, we find that this effect is more pronounced for loan-years with tighter slack. Also, within the sub-sample of loan-years with tighter slack, we find that real earnings management is higher for borrowers that experienced increases in bankruptcy risk in the previous year. Finally, we find that firms that manage real activities are more likely to violate debt covenant in the future. Our results suggest that firms use real earnings management to avoid costly debt covenant violations, complementing the mixed results in the literature regarding the relation between accrual earnings management and debt covenant violations. Our results are robust to controlling for endogeneity of the tightness of debt covenant slack, modeling the simultaneity in accrual and real earnings management choices, and controlling for performance as a potential driver of both slack tightness and real earnings management.
\end{abstract}

Keywords: debt covenants, debt covenant slack, real earnings management, Dealscan

JEL Classification: M40, M41

Data availability: all data is available from commercial sources identified in the text. 


\section{Introduction}

We examine whether real earnings management is more pronounced when firms get closer to potential violations of their net worth debt covenants, i.e. when firms have tighter debt covenant slacks. We further examine whether this relation is more pronounced for firms with tighter slack, and for firms that are expected to incur higher costs when renegotiating their debt contracts. Finally, to determine if real earnings management is myopic, we investigate whether firms that manipulate real activities are more likely to breach debt covenants in the future.

Positive Accounting Theory's Debt Covenant Hypothesis predicts that firms with tighter slack are likely to make accounting choices to avoid covenant violations (Watts and Zimmerman, 1986). However, the expected effects of bank monitoring and auditors' litigation risk on earnings management behavior have not been considered. Making income-increasing accounting choices or accruals is a type of moral hazard action that delays timely violations of covenants, which potentially goes against lenders' objectives. ${ }^{1}$ Thus, lenders would monitor borrowers in order to prevent these self-interested actions of borrowers (Diamond, 1984). In addition, because auditors face an asymmetric litigation risk function, they have incentives to minimize income-increasing accruals in the presence of accounting-based covenants (Nikolaev, 2010). ${ }^{2}$ Hence, it is unclear whether borrowers could successfully manipulate accruals or accounting choices in order to avoid debt covenant violations.

\footnotetext{
${ }^{1}$ As Dichev and Skinner (2000) note, debt covenants are set tightly in order to serve as a "trip-wire" monitoring devise. Thus, when covenant violations occur, borrowers' control rights shift to lenders who can take actions to minimize expected losses to their investments. For that reason, debt contracts specify accounting method and/or could demand detailed accounting information (e.g. aging report of accounts receivables) to ensure that borrowers book negative news in a timely manner.

${ }^{2}$ Nikolaev (2010) notes that auditors have to certify their clients' compliance with debt covenants.
} 
Consistent with these conflicting theoretical arguments, empirical evidence on the debt covenant hypothesis is also mixed. For example, Defond and Jiambalvo (1993) find that in the year preceding debt covenant violations, violating firms experience increases in total accruals. Sweeney (1994) also documents that firms make income-increasing accounting choices before violations. However, she finds no difference in accounting choices between violators and non-violators in multivariate regressions. Similarly, Healy and Palepu (1990) do not find evidence that firms make income-increasing accounting choices in order to avoid compliance with dividend-restricting debt covenants. ${ }^{3}$ Moreover, DeAngelo et al. (1994) find that distressed firms facing debt covenant violations make discretionary write-offs and other accrual decisions to reduce income.

We focus on real earnings management to avoid debt covenant violations because real earnings management, as opposed to accrual earnings management, is less likely to draw regulatory scrutiny and additional monitoring by lenders (Roychowdhury 2006, Cohen et al. 2008, Zhang, 2007, Cohen and Zarowin, 2010). This is because structuring debt contracts on the basis of the optimal level of operations is too costly or impossible, and US security laws do not penalize managers for sub-optimal operating decisions. Prior research has found some indirect evidence suggesting the possible use of real earnings management to avoid debt covenant violations (Roychowdhury, 2006; Bartov, 1993; Haw et al., 1991). These studies, however, either use the debt-to-equity ratio or the presence of debt as an indirect proxy of debt covenant slack and/or focus on a single facet of real earnings management. We directly examine the association between debt covenant slack and multiple channels of real earnings management.

\footnotetext{
${ }^{3}$ Healy and Palepu (1990) still find that firms comply with dividend restrictions.
} 
Using net worth covenant data from Dealscan between 1990 and 2008, we find that the extent of real earnings management is positively associated with the tightness of net worth covenant slack. We further find that our results are stronger for loan-years with smaller net worth covenant slack, i.e. in cases when incentives to avoid debt covenant violations are particularly strong. We also find that our results are more pronounced for the firms that experience an increase in bankruptcy risk in the previous year, i.e., when the expected cost of covenant violations is higher.

Finally, we examine of the myopic nature of real earnings management. While real earnings management helps firms achieve short term performance goals, it has a potential negative impact on future operating performance (Cohen and Zarowin, 2010). Consistent with this prediction, we find that borrowers engaging in real earnings management are more likely to breach covenants in the future.

In the robustness checks, we address three concerns. First, because debt covenant slack is a function of firm/loan characteristics, the relation between real earnings management and debt covenant slack could be subject to a correlated omitted variable bias. To address this issue, we construct a model of determinants of debt covenant slack and re-examine our results after accounting for endogeneity. The tenor of our results does not change.

Second, an alternative explanation to our findings is that deteriorating performance is associated with both tighter debt covenant slack and activities which manifest themselves as real earnings management. That is, one may argue that borrowers that have tighter debt covenants are facing difficult economic circumstances and consequently exhibit lower 
margins, increases in over-production (due to missed demand targets), as well as reductions in discretionary expenses. However, assuming that this explanation is true, due to the transient nature of losses, bad performance should revert to better performance in the next period, and thus, we should observe a lower likelihood of future debt covenant violations. We observe the opposite. Furthermore, when we partition our sample by several measures of performance, we find that our results are present in both poor- and better-performing firms, which again, suggests that our results are not driven by performance.

Third, accruals and real activities are alternative ways to manage earnings and thus, they could be simultaneously determined. We entertain this possibility by constructing a system of simultaneous equations for accrual and real earnings management. Our results are robust to this consideration.

We contribute to the debt covenant literature by providing empirical evidence suggesting that firms manage real activities to avoid covenant violations, complementing the mixed results found in this literature regarding whether firms manage accruals/accounting choices to avoid covenant violations. We also contribute to the growing literature on real earnings management activities. Recent studies suggest that real earnings management is likely to be more pronounced in the presence of stronger opportunistic incentives to manage earnings, such as higher levels of fixed costs (Gupta, et al. 2010), SEOs (Cohen and Zarowin, 2009), seeking to avoid reporting losses (Roychowdhury, 2006), and generally higher levels of debt (Roychowdhury, 2006). We extend this literature to the private debt contract setting. Early work by Bartov (1993) and Haw et al. (1991) and a conjecture in Roychowdhury (2006) provide initial clues that real 
activities manipulation could be related to the structure of private debt contracts. We provide direct and robust evidence to that effect. We also provide evidence on the myopic nature of real earnings management, i.e., we show that firms engaging in real earnings management are more likely to violate debt covenants in the future. Finally, since we find that borrowers engage in value-destroying real activities to avoid debt covenant violations, our results provide additional credence to the fundamental assumption in the debt covenant literature that debt covenant violation is costly.

\section{Related Literature and Hypothesis Development}

\subsection{Debt Covenant Hypothesis and Accrual Earnings Management}

The debt covenant hypothesis assumes that debt covenant violations are costly and predicts that managers have incentives to make accounting choices to avoid default (Watts and Zimmerman, 1986). However, existing empirical evidence on the debt covenant hypothesis is mixed (Dichev and Skinner, 2000; Beneish, Press, and Vargus, 2001). Defond and Jiambalvo (1993) find that in the year preceding debt covenant violation, violating firms experience increases in total accruals and higher Jones model abnormal accruals, as compared to the year of covenant violation. Sweeney (1994) investigates 130 actual instances of default and finds univariate evidence only that firms make income-increasing accounting choices in the year preceding covenant violations. Dichev and Skinner (2000) find unusually larger number of firms slightly above debt covenants' violation thresholds than below, and interpret the evidence as indicating managers take actions to avoid covenant violations. 
Other studies, however, either do not find such supporting evidence or even find evidence of the opposite firm behavior. For example, Healy and Palepu (1990) find evidence that firms cut dividends to comply with dividend restricting covenants, but they do not find evidence that borrowers make accounting choices to avoid dividend reductions. Sweeney (1994) only finds univariate evidence that covenant violators tend to choose income-increasing accounting methods in the year prior to violation. Her multivariate regression estimation shows no difference in cash flow impact of accounting choices of covenant violators vs. non-violators. Moreover, DeAngelo et al. (1994) examine the accounting choices of distressed firms that are facing a binding debt covenant and find that these firms make discretionary write-offs and other accrual decisions to reduce (not increase) income. These results suggest no evidence of debt covenant violations playing a role in managers' accounting choices.

One explanation for these mixed results is that these studies do not take into account the potential effects of bank and/or auditor monitoring of accrual manipulation in the context of debt covenants. Kim (2010) finds that borrowers of single lender loans increase accounting conservatism more after debt contracts, as compared to the ones with syndicated lenders, arguing that bank monitoring forces borrowers to recognize bad news more timely. Beatty et al. (2008) also find that accounting conservatism increases after firms enter into debt contracts. These results suggest that bank monitoring effectively restricts accrual manipulation. Nikolaev (2010), on the other hand, argues that auditors are likely to be more cautious and exert a higher degree of conservatism in the presence of accounting-based covenants, suggesting auditors' litigation risk will prevent income increasing accruals of borrowers. 


\subsection{Debt Contracts and Real Earnings Management}

While debt contracts typically specify which accounting methods will be used for specific covenants or how financial covenant is calculated, it is impossible or too costly to contract on inventory levels or the amount of discretionary expenses because those decisions are contingent on future business environment. In other words, real earnings management might be myopic in nature, but debt contracts cannot contract on the optimal level of operations and security laws do not penalize managers for sub-optimal decisions. Thus, real earnings management is less likely to be monitored by lenders. In addition, managers and auditors of borrowers face a lower risk of litigation with real earnings management because verification is much more difficult. Consistent with these arguments, Graham et al. (2005) show that financial executives indicate a greater willingness to manipulate earnings through real activities rather than accruals. Since managers have more flexibility and lower risk in manipulating real activities compared to accrual management, we argue that, if violations of debt covenants are costly to firms, managers may engage in real earnings management to avoid the violations.

Prior research finds some initial evidence of the use of real earnings management to avoid debt covenant violations. Roychowdhury (2006) finds that real earnings management is higher for firms with debt compared to firms without debt. Similarly,

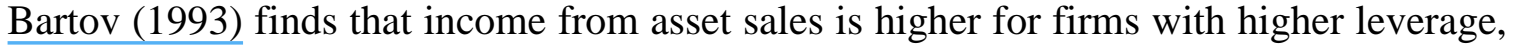
with higher leverage serving as a proxy for more restrictive debt covenants. Haw et al. (1991) find some evidence that the presence of public debt covenants and higher leverage are associated with a greater likelihood of settling over-funded pension obligations, 
resulting in partial settlement gain recognition in earnings and the avoidance of debt covenant violations.

All of these studies suggest that the incentive to avoid debt covenant violations could motivate managers to engage in real activities manipulations. However, these studies face the same basic limitation. First, they use the debt-to-equity ratio or the presence of debt as an indirect proxy of debt covenant slack (Fields et al., 2001). Second, Bartov (1993) and Haw et al. (1991) focus on only some specific manifestations of real activities manipulation, such as asset sales, or pension fund settlements. As Roychowdhury (2006) points out, the menu of real activity manipulation choices is potentially much broader because it includes manipulation of inventory over-production decisions, discretionary expenses, and sales margins. Our study overcomes these limitations by focusing on a menu of real activities and examining the direct relation between real earnings management and debt covenant slack.

We define debt covenant slack as the difference between a pre-specified financial ratio threshold in the contract and actual ratio of the firm. Since the likelihood to breach debt covenants increases with the tightness of the slack, we conjecture that borrowers have stronger incentives to manipulate real activities when the tightness of slack increases. Hence, our first hypothesis (stated in alternative form) is

H1: Firms are more likely to engage in real earnings management as debt covenant slack becomes tighter.

Prior literature shows that firms are more likely to manipulate real activities when this manipulation is most beneficial. For example, Roychowdhury (2006) finds that firms 
close to missing analyst expectations and/or reporting losses have higher levels of real earnings management. Bushee (1998) shows that pressure from transient institutional investors affects managers' decisions to cut R\&D in order to avoid missing earnings targets. Along the same lines, we expect managers to use real earnings management to a greater extent when firms have a higher likelihood to breach covenants, i.e., when debt covenant slack is tighter. Hence, our second hypothesis (stated in alternative form) is

H1a: Borrowers are more likely to manipulate real activities when they are closer to the zero covenant slack thresholds.

In addition, managers are more likely to resort to real earnings management to avoid debt covenant violations when they expect the consequences of covenant violations to be most unfavorable. When the lender perceives that the default risk of a borrower has increased since the inception of borrowing, a lender could impose on the borrower less favorable terms (for example, reductions in loan principal or higher interest rate), or in the extreme case call on the loan altogether (Chen and Wei, 1993, Roberts and Sufi, 2009b). This suggests that a borrower with an increased bankruptcy risk should have stronger incentives to take actions to avoid covenant violations ex-ante instead of attempting to renegotiate ex-post, leading us to the following prediction:

H1b: Increased bankruptcy risk will strengthen the incentives to manage real activities for the firms that are close to covenant violations.

While real earnings management helps firms to achieve short term goals, it has a potentially negative impact on future operating performance because of its potentially value-destroying nature (Cohen and Zarowin, 2010). In other words, just like accrual 
earnings management, real earnings management eventually "reverses", i.e. firms cannot keep doing it forever. This reasoning suggests that borrowers that engage in real earnings management to avoid imminent covenant violation are more likely to breach covenants in the future. Hence our last hypothesis (stated in alternative form) is

H2: Firms that engage in real earnings management are more likely to violate debt covenants in the future.

\section{Research Design and Sample}

\subsection{Research Design}

\subsubsection{Proxies for Real Earnings Management}

We follow Roychowdhury (2006) and Cohen et al. (2008) in defining our proxies for real earnings management. Specifically, we focus on three proxies of real earnings manipulation: abnormal cash flow (Abn_CFO), abnormal production costs (Abn_Prod), and abnormal discretionary expenses (Abn_Discexp):

1. ABN_CFO: Firms can boost sales volumes temporarily though increased price discounts or more lenient credit terms. However, both price discounts and more lenient credit terms will result in lower cash flows in the current period.

2. ABN_Prod: Firms can report lower cost of goods sold through increased production. When firms produce more units than necessary, they can spread the fixed overhead costs over a larger number of units, lowering fixed costs. 
Total cost per unit will decline as long as the reduction in fixed costs is not offset by increased marginal cost or inventory holding costs.

3. ABN_Discexp: Firms can decrease in discretionary expenses that include advertising expenses, research and development and SG\&A expenses.

Following Roychowdhury (2006) and Cohen et al. (2008), we first estimate the normal levels of cash flow, production costs, and discretionary expenses using the model developed by Dechow et al. (1998). Abnormal cash flow, production costs, and discretionary expenses are the difference between actual levels of these variables and the normal levels of the variables calculated using estimated coefficients from the equations below.Specifically, we estimate the normal level of cash flow using the following twodigit SIC code industry-year linear regressions.

$\mathrm{CFO}_{\mathrm{it}} /$ Assets $_{\mathrm{i}, \mathrm{t}-1}=\mathrm{a}_{1 \mathrm{t}}\left(1 /\right.$ Assets $\left._{\mathrm{i}, \mathrm{t}-1}\right)+\mathrm{a}_{2 \mathrm{t}}\left(\right.$ Sales $_{\mathrm{i}, \mathrm{t}} /$ Assets $\left._{\mathrm{i}, \mathrm{t}-1}\right)+\mathrm{a}_{3 \mathrm{t}}\left(\Delta\right.$ Sales $_{\mathrm{i}, \mathrm{t}} /$ Assets $\left._{\mathrm{i}, \mathrm{t}-1}\right)+\varepsilon_{\mathrm{it}}$ (A)

where $C F O$ is cash flow from operations.

Similarly, we estimate the normal level of production costs using the following industry-year regression model

$\operatorname{Prod}_{i t} / \operatorname{Assets}_{\mathrm{i}, \mathrm{t}-1}=\mathrm{b}_{1 \mathrm{t}}\left(1 / \operatorname{Assets}_{\mathrm{i}, \mathrm{t}-1}\right)+\mathrm{b}_{2 \mathrm{t}}\left(\operatorname{Sales}_{\mathrm{i}, \mathrm{t}} / \operatorname{Assets}_{\mathrm{i}, \mathrm{t}-1}\right)+\mathrm{b}_{3 \mathrm{t}}\left(\Delta \operatorname{Sales}_{\mathrm{i}, \mathrm{t}} / \operatorname{Assets}_{\mathrm{i}, \mathrm{t}-1}\right)$

$$
+\mathrm{b}_{4 \mathrm{t}}\left(\Delta \text { Sales }_{\mathrm{i}, \mathrm{t}-1} / \text { Assets }_{\mathrm{i}, \mathrm{t}-1}\right)+\mathrm{e}_{\mathrm{it}}
$$

where Prod is sum of cost of goods sold and change in inventory. 
Finally, we model discretionary expenses as a function of lagged sales and estimate the following industry-year regression model to derive normal levels of discretionary expenses ${ }^{4}$.

$\operatorname{Discexp}_{i t} /$ Assets $_{\mathrm{i}, \mathrm{t}-1}=\mathrm{c}_{1 \mathrm{t}}\left(1 /\right.$ Assets $\left._{\mathrm{i}, \mathrm{t}-1}\right)+\mathrm{c}_{2 \mathrm{t}}\left(\right.$ Sales $_{\mathrm{i}, \mathrm{t}-1} /$ Assets $\left._{\mathrm{i}, \mathrm{t}-1}\right)+\mathrm{v}_{\mathrm{it}}$

where Discexp is the sum of advertising expenses, R\&D expenses, and SG\&A expenses.

Abnormal cash flow (Abn_CFO), abnormal production costs (Abn_Prod), and abnormal discretionary expenses (Abn_Discexp) are the regression residuals from equations (A)(C), respectively.

Also, following Cohen et al. (2008), we develop a comprehensive measure of real earnings management by combing the three individual measures. Specifically, we compute REM_Index as the sum of the standardized three individual components, i.e., $A b n \_C F O+A b n \_P r o d-A b n \_D i s c e x p$. We standardize each individual component by its annual standard deviation. Higher levels of REM_Index indicate higher levels of overall real earnings management. We report results corresponding to the comprehensive real earnings management index (REM_Index) as well as the three individual real earnings management proxies (Abn_CFO,Abn_Prod, and Abn_Discexp).

\subsubsection{Tightness of Covenant Slack}

Following Chava and Roberts (2008), we combine net worth and tangible net worth covenant slack into a single net worth covenant slack variable. For net worth covenant, the tightness of covenant slack is defined as the required minimum net worth

\footnotetext{
${ }^{4}$ Cohen et al. (2008) argue that modeling discretionary expenses as a function of current sales creates a mechanical problem if firms manage sales upward to increase reported earnings in a certain year, resulting in significantly lower residuals.
} 
covenant threshold per Dealscan minus actual common equity (CEQ), deflated by prior year's total assets. For tangible net worth covenant, the tightness of covenant slack is defined as the required minimum tangible net worth covenant threshold per Dealscan minus (actual common equity less intangible assets), deflated by prior year's total assets. A larger (i.e., less negative) $T \_S L A C K$ identifies tighter covenants, i.e., covenants closer to violation.

\subsubsection{Empirical Models}

H1 predicts that firms will increase real earnings management as covenants slack becomes tighter to avoid costly violations. To test this, we estimate the following regression.

$R E M_{t}=a_{0}+a_{1} * T_{-} S L A C K_{t}+a_{2} * L A T_{t-1}+a_{3} * M T B_{t-1}+a_{4} * L E V_{t-1}+a_{5} * R O A_{t-1}+a_{6} * \Delta G D P_{t-1}$

$$
+a_{7} * D A_{t}+e_{t}
$$

where $R E M$ is one of real earnings management measures or REM_Index.

We follow Roychowdhury (2006) and Cohen et al. (2008) to control for various factors that affect cross-sectional variation in real earnings management ${ }^{5}$. To control for systematic variation in abnormal CFO, production costs and discretionary expenses with growth opportunities and size, we include $L A T$, defined as natural log of total assets for a firm, and $M T B$, or the market-to-book ratio. We also include leverage or $L E V$, defined as the ratio of total liabilities to assets, to investigate whether the tightness of slack has any

\footnotetext{
${ }^{5}$ Cohen et al.'s (2008) model also includes a number of executive compensation controls (such as executives' levels of salaries, bonus, stock options and restricted stock ownership levels). The lack of availability of these variables in conjunction with Dealscan data significantly reduces our sample size. Therefore, we do not use these variables in our main tests. However, we include them in our robustness tests, and our results remain consistent with those reported.
} 
additional relation with real earnings management in addition to the impact of leverage documented by prior literature (Roychowdhury, 2006, Bartov, 1993). Following Roychowdhury (2006), we include $R O A$, defined as the ratio of earnings before extraordinary items deflated by prior period assets, as a control variable for firm performance. This control is important because when firm performance is declining a firm could engage in restructuring activities which manifest themselves similar to real activities manipulation. $\triangle G D P$, defined as change in annual level of U.S. GDP as reported by the US Bureau of Economic Analysis, is included as a proxy for real economic activity because what might be classified as opportunistic earnings management may, in fact, be a consequence of changing economic conditions. According to Cohen et al. (2008), firms may follow an overall earnings management strategy and use a mix of real and accrual-based earnings management tools. Alternatively, they can choose between the two management techniques, using the technique that is less costly for them. To control for this possibility, it is important to include a variable representing accrual-based earnings management $(D A) . \quad D A$ is modified Jones (1991) model of discretionary accruals, with control for contemporaneous accounting performance as suggested in Kothari et al (2005).

We conjecture that the coefficient on $T_{-} S L A C K\left(\mathrm{a}_{1}\right)$ in model (1) will be positive for models that use REM_Index and $A B N \_P r o d$ as dependent variables, and negative for models that use $A B N_{-} C F O$ and $A B N_{-}$Discexp as dependent variables, suggesting borrowers manage real activities to a greater extent when their covenant slacks become tighter. 
H1a predicts that the extent of real earnings management is stronger for firms closer to the debt covenant threshold. To test H1a, we run the following regression model:

$$
\begin{aligned}
& R E M_{t}=b_{0}+b_{1} * T_{-} S L A C K_{t}+b_{2} * T_{-} S L A C K_{t} * C_{L O S E}+b_{3} * C L O S E_{t}+b_{4} * L A T_{t-1}+b_{5} * M T B_{t-} \\
& { }_{1}+b_{6} * L E V_{t-1}+b_{7} * R O A_{t-1}+b_{8} * \Delta G D P_{t-1}+b_{9} * D A_{t}+e_{t}
\end{aligned}
$$

where CLOSE is a dummy variable equal to one if the magnitude of $T \_S L A C K$ is between 0 and $10 \%$, and zero otherwise. This measures the degree of proximity to zero slack. We expect that $b_{2}$ and $b_{1}+b_{2}$ in model (2) will be positive for models using REM_Index and $A B N \_P r o d$ as dependent variables, and $b_{2}$ and $b_{1}+b_{2}$ will be negative for models using $A B N \_C F O$ and $A B N \_D i s c e x p$ as dependent variables because real earnings management will be more pronounced for the firms that are closer to covenant violations.

H1b predicts that the association between tighter debt covenant slack and real earnings management is stronger for firms that experience increases in bankruptcy risk because the cost of covenant violation is higher. To test H1b, we run the following regression model:

$$
\begin{aligned}
& R E M_{t}=c_{0}+c_{1} * T_{-} S L A C K_{t}+c_{2} * T_{-} S L A C K_{t} * \operatorname{CLOSE}_{t}+c_{3} * T_{-} S L A C K_{t} * \operatorname{CLOSE}_{t} * \Delta B A N K_{t-1} \\
& +c_{4} * T_{-} S L A C K_{t} * \Delta B A N K_{t-1}+c_{5} * C L O S E_{t} * \Delta B A N K_{t-1}+c_{6} * C L O S E_{t}+c_{7} * \Delta B A N K_{t-1} \\
& +c_{8} * L A T_{t-1}+c_{9} * M T B_{t-1}+c_{10} * L E V_{t-1}+c_{11} * R O A_{t-1}+c_{12} * \Delta G D P_{t-1}+c_{13} * D A_{t}+e_{t}
\end{aligned}
$$

where $\triangle B A N K$ is a dummy variable equal to one if a firm experiences an increase in estimated default frequency (Merton KMV Measure of bankruptcy risk, estimated using an algorithm in Bharath and Shumway, 2008) in the prior year. Under H1b we expect that $c_{3}$ and $c_{1}+c_{2}+c_{3}+c_{4}$ in model (3) will be positive for models using REM_Index and 
$A B N_{-}$Prod as dependent variables, and $c_{3}$ and $c_{1}+c_{2}+c_{3}+c_{4}$ will be negative for models using $A B N \_C F O$ and $\mathrm{ABN} \_$Discexp as dependent variables, implying borrowers have stronger incentives to engage in real earnings management when the likelihood of debt covenant violation is stronger (slack is tighter) and expected renegotiation costs are higher (ex-ante bankruptcy risk is higher).

$\mathrm{H} 2$ predicts that firms that manage real activities to a greater extent are more likely to violate net worth debt covenant in the future. We examine debt covenant violations in the next year. ${ }^{6}$ To test $\mathrm{H} 2$, we run the following logit regression model:

Future_viol $l_{t+1}=d_{0}+d_{1} * D A_{t}+d_{2} * R E M_{-} I n d e x_{t}+d_{3} * L A T_{t-1}+d_{4} * L E V_{t}$

$+d_{5} * R O A_{t}+d_{6} * Z_{-}$score $_{t}+d_{7} * \log (\text { Maturity })_{t}+d_{8} * N_{-}$Covenants $_{t}+d_{9} * \log (\text { Age })_{t}+e_{t}$

where Future_Viol $t_{t+1}$ is a dummy variable equal 1 if a borrower violates the net worth debt covenant in year $\mathrm{t}+1$. Z_Score is Altman Z-score, Log(Maturity) is natural logarithm of the remaining maturity of the loan, $N_{-}$Covenants is the total number of covenants in a particular loan, and $\log (\mathrm{Age})$ is natural logarithm of the firm age. Other variables are as defined earlier. Under $\mathrm{H} 2$ we expect that $d_{2}$ in model (4) will be positive. If accrual earnings management leads to negative consequences, i.e., firms that manage accruals to avoid imminent debt covenant violations are more likely to violate covenants in the future, $d_{l}$ will be positive too.

To mitigate the influence of potential outliers, we winsorize all continuous variables in all models at their respective $1^{\text {st }}$ and $99^{\text {th }}$ percentiles. Following Gow et al. (2010), we report all test statistics based on the two-way cluster-robust standard errors (cluster by

\footnotetext{
${ }^{6}$ Our results are robust to examining debt covenant violations in the next two years.
} 
firm and by year), which adjust for both cross-sectional and time-series dependence in panel data.

\subsection{Sample and descriptive statistics}

\subsubsection{Sample Selection}

We obtain a sample of all loans with net worth and tangible net worth debt covenants from Dealscan and match it with Compustat using a matching dataset provided by Michael Roberts and originally used in Chava and Roberts (2008). ${ }^{7}$ Because Dealscan does not have a corresponding matching identifier to Compustat (such as ticker or CUSIP), Michael Roberts provides a matching dataset that can be used to merge Dealscan and Compustat data . To the extent feasible, we also manually match Dealscan and Compustat data for observations not available in Michael Roberts' matching dataset. Our sample period starts in 1990 and ends in 2008. We require Compustat data availability of real earnings management measures, as well as prior year size, ROA, leverage, market-to-book, and discretionary accruals measures. We exclude any observations with positive $T \_S L A C K$ (i.e. firms in technical default) from our sample. We exclude these observations for two reasons. First, technical default firms have already violated their covenants and hence it is unclear whether they have further incentives to manage earnings through real activity manipulations; and second, it is possible that positive $T \_S L A C K$ can be a result of an unobservable subtlety in the definition of the covenant (Chava and Roberts, 2008). ${ }^{8}$ This sample selection procedure results in a

\footnotetext{
${ }^{7}$ Chava and Roberts (2008) examine how violations of net worth and current ratio debt covenants impact firms' investment policy.

${ }^{8}$ Dichev and Skinner (2002) and Chava and Roberts (2008) both encounter this phenomenon of covenant violations in the quarter of the loan origination.
} 
sample of 4,249 loan-years. We use this sample to estimate models (1) and (2). Model (3) requires availability of lagged changes in estimated default frequency, which reduces our sample size to 3,727 loan-year observations. Finally, estimation of model (4) requires data availability on the level of next year's covenant slack resulting in a sub-sample of 2,810 loan-year observations.

\subsubsection{Descriptive Statistics}

Table 1 presents descriptive statistics for our sample. Panel A summarizes descriptive statistics for $\mathrm{H} 1, \mathrm{H} 1 \mathrm{a}$, and $\mathrm{H} 1 \mathrm{~b}$. The means of the amount of real earnings management variables, i.e., abnormal cash flow, abnormal production, and abnormal discretionary expenditures are $0.024,-0.001$, and -0.002 , respectively. The mean of REM_Index is 0.007 and the median is -0.049 . Since we exclude all firms already in technical default, all our firms have negative $T \_S L A C K$. The mean of $T \_S L A C K$ is -0.214 and the median is -0.159. The mean of Lev is 0.605 , suggesting that companies finance their assets with $60.5 \%$ of debt. Because debt is a significant source of financing for these companies, they will have strong incentives to avoid covenant violations due to the potential discontinuity of projects from covenant violations. Panel B summarizes descriptive statistics for $\mathrm{H} 2$. In our sample, 9.5 percent of firms violate net worth debt covenants in the following year.

Table 2 presents the pair-wise Pearson correlations. Panel A presents these correlations for variables in testing $\mathrm{H} 1, \mathrm{H} 1 \mathrm{a}$, and $\mathrm{H} 1 \mathrm{~b}$. REM_Index is positively correlated with $T \_S L A C K$, consistent with firms managing real activities to avoid the net worth debt covenant violations. Furthermore, this correlation table suggests that firms manage each of the three components of real activities, i.e., cash flows, production and 
discretionary expenditures, to avoid violating net worth covenants. T_SLACK has a positive relation with $L E V$ and a negative relation with $R O A$, suggesting slack is set tight for highly leveraged firms and less profitable firms.

Panel B presents correlations for variables in testing H2. REM_Index is positively correlated with Future_viol, suggesting that firms managing real activities to avoid imminent net worth debt covenant violations are more likely to violate debt covenants in the following year, consistent with $\mathrm{H} 2$. Results show that smaller firms and less profitable firms are more likely to breach covenants. Firms with shorter maturity loans, greater number of covenants, lower Altman Z-score, and high leverage have a higher likelihood to breach covenants, consistent with the argument that covenants are a warning device for riskiness of borrowers (Dichev and Skinner 2002).

\section{Empirical Results}

\subsection{Main Results}

Table 3 presents the regression results for $\mathrm{H} 1$. We find a positive coefficient of 0.927 ( $t=4.65)$ on $T_{-} S L A C K$ in the REM_Index regression, suggesting that firms manage more real activities when their net worth covenant slack is tighter, i.e., they manage real activities to avoid violating net worth covenant violations. Coefficients with respect to control variables are consistent with prior literature (Roychowdhury 2006, Cohen et al. 2008). We find a positive coefficient on $L E V$ and a negative coefficient on ROA, suggesting firms with higher leverage and poor performance have stronger incentives to manage real activities to avoid a negative consequence from debt contracts. When we 
look at each component of real earnings management, we find the coefficient on $T \_S L A C K$ to be negative $(t=-2.59)$ in the $A B N \_C F O$ regression, positive $(t=2.24)$ in the $A B N \_$Prod regression, and negative $(t=-4.55)$ in the $A B N \_$Discexp regression. These results suggest that firms reduce abnormal cash flows, increase abnormal production and cut down abnormal discretionary expenditures to avoid violating net worth covenant violations. Overall, our results are consistent with $\mathrm{H} 1$.

Since H1a predicts that firms have stronger incentives to manage earnings when their covenant slack is the tighter, we test whether firms manage real activities to a larger extent when their net worth covenant slack is close to zero. We present our model (2) results in Table 4. Consistent with H1a, we find a positive coefficient of $3.626(t=1.75)$ on $T_{-} S L A C K^{*} C L O S E$ in the REM_Index regression, suggesting that firms that are close to violating their net worth covenants are more likely to manage real activities than other firms. We further examine the total effect of $T_{-} S L A C K$ on REM_Index for firms with $C L O S E=1$, i.e., the association between $T \_S L A C K$ and real earnings management for firms that are close to violating these covenants. The sum of the coefficient on T_SLACK and $T \_S L A C K^{*} C L O S E$ is 4.578 , which is significantly positive ( $\left.t=2.21\right)$, suggesting that firms that are close to net worth covenant violations are more likely to manage real activities to avoid such violations. When we further examine the components of real activities manipulation, we find that these firms mainly reduce their abnormal cash flows and cut back their discretionary expenditures to accomplish their real earnings management goals.

Since $\mathrm{H} 1 \mathrm{~b}$ predicts that bankruptcy risk increases the cost of covenant violations, we expect that our model (2) results are stronger when firms experience an increase in 
bankruptcy risk in the prior year. We report the regression results of model (3) in Table 5. Consistent with $\mathrm{H} 1 \mathrm{~b}$, we find a positive coefficient of $9.343 \quad(t=2.67)$ on $T \_S L A C K^{*} C L O S E^{*} \triangle B A N K$ in the REM_Index regression, suggesting that firms that are close to violating their net worth covenants are more likely to manage real activities when they experience an increase in bankruptcy risk than firms that do not experience an increase in bankruptcy risk. Furthermore, we examine the total effect of $T \_S L A C K$ on REM_Index for firms with $C L O S E=1$ and $\triangle B A N K=1$, i.e., the association between $T \_S L A C K$ and real earnings management for firms that have the strongest incentives to avoid these covenant violations (i.e., firms that are close to violate covenants and experience an increase in bankruptcy risk). The sum of the coefficient on T_SLACK, T_SLACK*CLOSE,T_SLACK*CLOSE* $\triangle B A N K$, and T_SLACK* $\triangle B A N K$ is 8.834, which is significantly positive $(t=4.20)$, suggesting that firms that are close to net worth covenant violations and experience an increase in bankruptcy risk overall manage real activities to avoid such violations. When we further examine the components of real activities manipulation, we find that these firms accomplish their real earnings management goals mainly through decreasing their abnormal cash flow and increasing their abnormal production.

In Table 6, we examine the relation between real earnings management and future debt covenant violations to test $\mathrm{H} 2$. To confirm the prior literature's results (e.g. Defond and Jiambalvo, 1994), we first examine whether accrual earnings management is associated with future net worth debt covenant violations. We find a positive coefficient of 0.067 on $D A(t=1.70)$, suggesting that firms that manage accruals to a greater extent are more likely to violate net worth debt covenant in the next year. This finding is 
consistent with reversal of managed accruals. We then add REM_Index as a regressor and find a positive coefficient of 0.089 on REM_Index $(t=2.06)$, suggesting that firms that manage real earnings to a greater extent are more likely to violate net worth debt covenant in the next year. This finding is consistent with a negative consequence of managing real activities. As such, our results provide support to the earlier argument that real earnings management is myopic because it leads to a higher likelihood of future debt covenant violations.

\subsection{Controlling for Endogeneity of $T \_S l a c k$}

In our primary analyses, we assume that creditors do not structure debt covenants to fully anticipate real earnings management. This assumption underlies many studies in the Debt Covenant Hypothesis literature. As Fields et al. (2001) argue, evidence exists to support this assumption on the basis of the demonstrated inability of sophisticated intermediaries to anticipate accruals earnings management. ${ }^{9}$ Lenders might find it more difficult to predict real earnings management than accrual earnings management or opportunistic accounting choices because real activity manipulations could take multiple forms, all of which could be too difficult to write in a complete contract. Also, when contracts are negotiated, managers are less likely to agree to ex-ante future restrictions in real activities because such activities could be value-maximizing business decisions. ${ }^{10}$

\footnotetext{
${ }^{9}$ Fields et al. (2001) cite findings that sophisticated intermediaries, such as analysts, cannot see through accounting choices. That is, development of sophisticated statistical models to detect earnings management in general is costly, and lenders may lack sophisticated knowledge to do it (see page 289 of Fields et al., 2001).

${ }^{10}$ For example, it is hard for lenders to ex-ante restrict managers from future R\&D cuts or from decisions to over-produce because ex-ante the optimal levels for such decisions are unknown.
} 
Nonetheless, to mitigate endogeneity concerns, we employ a two-stage procedure similar to Nikolaev (2010), which models the endogeneity of debt covenants in public debt contracts. The first stage model estimates abnormal tightness of net worth covenant slack $\left(A B N \_T \_S L A C K\right)$. Roychowdhury (2006) shows that real earnings management is more pronounced among firms that experience lower levels of accounting performance, have more long term debt and more current liabilities, are smaller, and have lower growth options. Manufacturing firms are also more likely to resort to real earnings management. The presence of these firm characteristics could lead lenders to set tighter initial slack. In addition, El-Gazzar and Patena (1991) show that the slack is a function of the number of covenants present in a particular debt contract. Nikolaev (2010) also shows that the degree of restrictiveness of public debt covenants varies with changes in firm leverage, asset tangibility (ratio of fixed assets to total assets), ${ }^{11}$ dividend yield, credit rating of the borrower, Altman Z-score, and remaining maturity and amount of the loan. We use all of these variables to construct the first stage model:

$1^{\text {st }}$ stage equation: $T_{-} S L A C K_{t}=a_{0}+a_{1} * L A T_{t-1}+a_{2} * B T M_{t-1}+a_{3} * L E V_{t-1}+$ $a_{4} * R O A_{t-1}+a_{5} * \operatorname{Loss}_{t}+a_{6} * 4 L E V_{t-1}+a_{7} * D_{I} V_{-}$YIELD $_{t-1}+a_{8} *$ TANGIBILITY $_{t-1}+a_{9} *$ $Z_{-}$Score $_{t-1}+a_{10} * C L_{t}+a_{11} * \log (\text { Maturity })_{t}+a_{12} * N C R_{t}+a_{13} * M F G_{t}+a_{14} * N_{-}$Covenants $_{t}$ $+a_{15} * \log (\text { Amount })_{t}+a_{16} * N O A_{t-1}+e_{t}$

In this model, $B T M$ is book-to-market ratio, $\triangle L E V$ is change in overall leverage, DIV_YIELD is the dividend yield of a firm (ratio of total dividends paid to stock price), TANGIBILITY is the ratio of net fixed assets to total assets, $C L$ is the ratio of current liabilities to total assets, $N C R$ is a dummy variable equal to 1 if a firm does not have a

\footnotetext{
${ }^{11}$ See also, Gupta, Pevzner and Seethamraju (2010) who show that inventory over-production is affected by the ratio of fixed assets to total assets.
} 
long-term credit rating in Compustat, $M F G$ is a dummy variable for manufacturing firms (SIC codes between 2000 and 3999), $\log$ (Amount) is natural logarithm of the amount of the loan, and NOA is the level of a firm's net operating assets deflated by prior year assets (used to control for earnings management constraint per Barton and Simko, 2002 and Cohen and Zarowin, 2009). All other variables are as defined earlier.

We obtain the residuals $e_{t}\left(A B N_{-} T_{-} S L A C K\right)$ from the first-stage model (5). To control for endogeneity, in the second stage, we replace $T \_S L A C K$ with $A B N \_T \_S L A C K$ in our regression model (1) following the methodology in Nikolaev (2010). ${ }^{12}$ Intuitively, one can think of $A B N \_T \_S L A C K$ as an instrumental variable for $T \_S L A C K$; while it is correlated with $T \_S L A C K$, by construction, it is uncorrelated with other variables that endogenously determine $T \_S L A C K$. We report the two-stage results in Table $7 .{ }^{13}$ Panel A reports our first stage results. Consistent with the argument that covenant slack is set tighter for borrowers with higher agency costs, slack is tighter for the firms with high leverage, dividend yield, loan amount, and low tangibility, current ratio, and net operating asset. Our results also show that loss firms and higher bankruptcy risk firms have tighter slacks. Panel B report our second stage results for model (1). Consistent with

\footnotetext{
${ }^{12} \mathrm{We}$ also conduct three additional analyses to address the endogeneity of $T \_S L A C K$. First, we follow Carcello et al. (2010) and add $A B N_{-} T \_S L A C K$ as an additional regressor in our model (1). We continue to find significant coefficients on $T \_S L A C K$ in all four regressions, all signs consistent with our predictions in H1. Second, we again follow Carcello et al. (2010) and use Stata's SUEST command to simultaneously estimate Model (1) and Model (5). Again, we continue to find significant coefficients on T_SLACK in all four regressions, and the signs are consistent with our predictions in H1. Second, we use Stata's IVREGRESS command to estimate Model (1) where the first-stage model is specified as in Model (5). We continue to find significant coefficients on $T_{-} S L A C K$ in all four regressions, all signs consistent with our predictions in H1. In summary, our results are robust to controlling for endogeneity of the tightness of net covenant slack. We do not tabulate these additional endogeneity analyses results for brevity.

${ }^{13}$ We do not report the results of Models (2) and Model (3) after controlling for endogeneity of $T \_S L A C K$ because there is no econometrically sound way to correctly address the endogeneity issue when the endogenously determined variable $\left(T \_S L A C K\right)$ appears in two-way (e.g., $\left.T \_S L A C K^{*} C L O S E\right)$ and threeway (T_SLACK ${ }^{*} C L O S E^{*} \triangle B A N K$ ) interaction terms. To add to the complexity, our CLOSE variable is an indicator variable defined based on $T_{-} S L A C K$, which is endogenously determined. Thus, it is empirically very difficult, if not impossible, to correctly control for endogeneity in Models (2) and (3).
} 
H1 and our Table 3 results, we continue to find a positive coefficient on ABN_T_SLACK in the REM_Index $(t=2.38)$ and a negative coefficient in the $A B N \_$Discexp $(t=-2.14)$ regressions. These findings suggest that our conclusion that tighter net worth covenant slack is associated with higher levels of real earnings management is largely robust to controlling for the endogeneity of the tightness of slack.

\section{Robustness Checks}

\subsection{Partition by Performance}

One might argue that our results are driven by failure to adequately control for borrowers' performance although we include $R O A$ in all our regression models. In other words, poor performance of borrowers drives debt covenant slack tighter and causes lower cash flows, reductions in discretionary expenses, or higher inventory. First, our evidence that borrowers with higher real earnings management are more likely to breach covenants in the future suggests that this alternative explanation is unlikely. If this alternative explanation is true, we should observe that high real earning management firms today will have lower likelihood of covenant breaches in the future because currently poorly-performing firms should experience an improvement in performance in the future, assuming mean-reversion of income.

To further rule out this alternative explanation, we partition our sample by various lagged performance measures and show in Table 8 that our results are not driven by poor performing firms. ${ }^{14}$ First, we partition by the ROA level. For firms with ROA below median (i.e., Low ROA group) and firms with ROA above median (i.e., High ROA

\footnotetext{
${ }^{14}$ We obtain similar results when we partition by contemporaneous performance measures. For brevity, we do not report these results in the paper.
} 
group), we find positive coefficients on T_SLACK suggesting that tighter covenant slack is associated with greater real earnings management for both poor and better performing firms. Similarly, when we partition by a loss indicator variable, earnings changes, and Altman Z-score (which indicates bankruptcy risk), we find that tighter covenant slack is associated with greater real earnings management for both poor (i.e., Loss=1 firms, earnings decrease firms, and Altman Z-score decrease firms) and good performing firms (i.e., Loss=0, earnings increase firms, and Altman Z-score increase firms). Overall, our findings indicate that our main results are present in both poor and good performing firms, suggesting that the results we document earlier is not driven exclusively by poor firm performance.

\subsection{Modeling Simultaneity of Real and Accrual Earnings Management}

Real activities and accruals are alternative ways to manage earnings. That is, firm managers may jointly determine the level of real and accrual earnings management. To entertain this possibility, we examine a simultaneous equation system for our real and accrual earnings management proxies. We model real and accrual earnings management as follows:

REM_Index $=f\left(T \_S l a c k, D A\right.$, Instruments, Controls $)+e$

$D A=g\left(T \_S l a c k, R E M \_I n d e x\right.$, Instruments, Controls $)+e$

Note that this structure allows both for the possibility of joint determination of REM_Index and $D A$, and their sequential determination (if one is more costly than the other to managers). Following Chan et al. (2010), we use the median levels of REM_Index as an instrumental variable to identify the real earnings management 
equation and the median levels of $D A$ as an instrumental variable to identify the accrual earnings management equation. Panel A of Table 9 presents our real earnings management regression results. ${ }^{15}$ In the first column, we do not include control variables but in the second column we do. Both columns present similar results. Overall, we continue to find positive coefficients on $T \_S L A C K$ in both real earnings management regression, suggesting that firms with tighter net worth covenant slacks are more likely to manage real earnings, consistent with H1. Panel B of Table 9 presents our accrual earnings management regression results. We fail to find significant relations between $T \_S L A C K$ and accrual earnings management after accounting for the simultaneity of real and accrual earnings management. Taken together, our $\mathrm{H} 1$ results are robust to controlling for the simultaneity of both real and accrual earnings management.

\subsection{Pre and post-SOX analyses}

Cohen et al. (2008) show that real earnings management increased after the adoption of the Sarbanes-Oxley Act (SOX). Their findings suggest that the association between the tightness of the net worth covenant slack and real earnings management could be more prominent post-SOX. To test this conjecture, we re-run models (1) after including the interaction of $T_{-} S L A C K$ with $S O X$, where $S O X=1$ if a firm has a fiscal year after 2004 and 0 if it is before 2003. We exclude 2003 from our analysis since it was a transitional period for SOX. We also include the main effect of SOX in the model. We exclude the year dummies because those are redundant with the SOX dummy. Our results (untabulated for brevity) show that the interaction $T_{-} S L A C K^{*} S O X$ is not significant

\footnotetext{
${ }^{15}$ Again, we do not report the results of Models (2) and Model (3) after accounting for the simultaneity of real and accruals earnings management because of econometric difficulties.
} 
except in the $A B N \_$Prod regression, while the main effect on $T \_S L A C K$ stays consistent with those reported in Tables 3-5. Untabulated tests regarding the total effect of $T \_S L A C K$ on real earnings management variables (the sum of the coefficients on $T \_S L A C K$ and $\left.S O X * T \_S L A C K\right)$ suggest that firms manage the overall level of real activities through all three types (i.e., abnormal cash flow, abnormal production, and abnormal discretionary expenditures) to avoid violating net worth covenant post-SOX. Overall, these results suggest that firms use real activities manipulation to avoid debt covenant violations both before and after SOX adoption, and that SOX largely did not affect their propensity to do so, possibly because incentives to avoid debt covenant violations are strong both before and after SOX.

\subsection{Managerial compensation}

Following Cohen et al. (2008), we also control for the level of unexercised stock options, exercised stock options, managerial bonus and salary obtained from ExecuComp. Our results remain similar to those reported.

\section{Conclusions}

Prior studies (Defond and Jiambalvo 1993, Sweeney 1994, Healy and Palepu 1990, DeAngelo et al. 1994) have examined accrual earnings management and accounting choices to avoid debt covenant violations with mixed results. We argue that real activities are less subject to bank monitoring and auditor litigation risk than accruals or accounting choices. As such, real earnings management presents a more powerful context to study firms' behavior to avoid debt covenant violations. Thus, our paper provides an alternative 
explanation to the mixed results in the literature examining the relation between accrual earnings management and debt covenant slack. Moreover, we provide an additional explanation on the mixed results in this literature, namely that firms elect to choose real earnings management over accrual earnings management when faced with the need to avoid debt covenant violations because accrual earnings management increases auditors' and borrowers' litigation risk, and is subject to increased bank monitoring.

We examine whether tighter net worth covenant slack is associated with greater levels of real earnings management. Using actual net worth debt covenant data from Dealscan, we find evidence consistent with this hypothesis. Moreover, we find that this result is more pronounced for loan years with tighter slack, and for firms experiencing increases in their bankruptcy risk in the prior year. Our results continue to hold after controlling for the endogeneity of debt covenant slack and after accounting for the simultaneity of accrual and real earnings management. Moreover, we show that our results are not driven by poor performance firms. Finally, we find that firms that manage real activities are more likely to violate debt covenants in the future. Hence, our findings provide further support for the Debt Covenant Hypothesis suggesting that managers will take real actions to avoid potentially costly debt covenant violations.

Some prior work finds that real earnings management is higher for firms with more debt (Bartov, 1993, Roychowdhury, 2006), and that some real earnings management activities are more pronounced in the presence of public debt covenants (Haw et al. 1991). Our study is the first to provide direct evidence that the tightness of private debt covenant slack affects real activity manipulations. Our focus on the direct measure of debt covenant slack provides an advantage over prior studies that focused on the level of a 
firm's leverage as a proxy for proximity to debt covenant violation. In addition, we provide evidence suggesting that real earnings management is myopic in nature because it is associated with a higher likelihood of future debt covenant violation. We also infer from this finding of managers' willingness to engage in value destroying real activity manipulations that they perceive debt covenant violations to be potentially costly. This is an important inference because some studies argue that private debt covenant violations are frequently waved, and therefore likely not to be very costly (Dichev and Skinner, 2002). Finally, we provide additional support to prior literature that finds that real earnings management is driven by incentives to manipulate earnings, such as avoiding missing earnings targets (Roychowdhury, 2006) or maximizing proceeds from SEOs (Cohen and Zarowin, 2009). Our results suggest that a tighter debt covenant is another context in which real activities manipulation is likely to occur. 


\section{References:}

Barton, J. and P. Simko (2002). Balance sheet as an earnings management constraint. The Accounting Review, 77, Supplement, 1-27.

Baber, W., P. Fairfield, and J. Haggard (1991). The effect of concern about reported income on discretionary spending decisions: the case of research and development. The Accounting Review, 66(4), 818-829.

Bartov, E., (1993). The timing of asset sales and earnings manipulation. The Accounting Review 68, 840-855.

Beatty, A., Ramesh, K., and Weber, J. (2002). The importance of accounting changes in debt contracts: the cost of flexibility in covenant calculations. Journal of Accounting and Economics, 33, 205-227.

Beneish, M. and E. Press (1993). Costs of technical violations of accounting-based debt covenants. The Accounting Review, 68(2), 233-257.

Beneish, M., Press, E., Vargus, M., 2001. The relation between incentives to avoid debtcovenant default and insider trading. Working paper, Indiana University, Temple University, and University of Texas at Dallas.

Bharath, S. and T. Shumway (2008). Forecasting Default with the Merton Distance to Default Model. Review of Financial Studies, 21(3), 1339-1369.

Bushee, B. (1998). The influence of institutional holders on myopic R \& D investment behavior. The Accounting Review, 73(3), 305-333.

Carcello, J. V., T. L. Neal, Z-V. Palmrose, and S. Scholz (2010). CEO Involvement in Selecting Board Members, Audit Committee Effectiveness, and Restatements. Contemporary Accounting Research (forthcoming).

Chan, L., T. Chen, S. Janakiraman, and S. Radhakrishnan (2010). Working paper. University of Texas-Dallas.

Chava, R. and M. Roberts (2008). How does financing impact investment? The role of debt covenants. Journal of Finance, 63, 2085-2121.

Chen, K. and K.C. Wei (1993). Creditors' decisions to waive accounting-based covenant violations. The Accounting Review, 68(2), 218-232.

Cohen, D., A. Dey, T. Lys (2008). Real and accrual-based earnings management in the pre and post-Sarbanes-Oxley periods. The Accounting Review, 82(3), 757-787.

Cohen, D. and P. Zarowin (2009). Earnings management and excess investment: Accrual-based versus Real Activities. Working Paper. New York University. 
Cohen, D. and P. Zarowin (2010). Accrual based and real earnings management activities around seasoned equity offerings. Journal of Accounting and Economics, forthcoming.

Core, J. and C. Schrand (1999). The effect of accounting-based debt covenants on equity valuation. Journal of Accounting and Economics, 27(1), 1-34.

DeAngelo, H., DeAngelo L., and D. Skinner (1994). Accounting Choice in Troubled Companies. Journal of Accounting and Economics, 17(1), 113-143.

Dechow, P., R. Sloan, and A. Sweeney (1996). Causes and Consequences of Earnings Manipulation: An Analysis of Firms Subject to Enforcement Actions by the SEC. Contemporary Accounting Research, 13(2).

Dechow, P., W. Ge, C. Larson, and R. Sloan (2007). Predicting material accounting manipulations. Working Paper. University of Michigan.

DeFond, M. and J. Jiambalvo (1994). Debt Covenant Violation and Manipulation of Accruals. Journal of Accounting and Economics $17,145-76$.

Dichev, I. and D. Skinner (2002). Large sample evidence on debt covenant hypothesis. Journal of Accounting Research, 40(4), 1091-1123.

El-Gazzar, S. and V. Pastena (1991). Factors affecting the scope and initial tightness of covenant restrictions in private lending agreements. Contemporary Accounting Research, $\underline{8(1), 132-151}$

Fields, T., T. Lys, and L. Vincent (2001). Empirical research on accounting choice. Journal of Accounting and Economics, 31(1), 255-307.

Gow, I. D., G. Ormazabal, and D. J. Taylor (2010). Correcting for Cross-Sectional and Time-Series Dependence in Accounting Research. The Accounting Review 85 (2), 483512.

Graham, J.R., Harvey, C.R., Rajgopal, S.(2005). The economic implications of corporate financial reporting. Journal of Accounting and Economics 40, 3-73.

Gupta, M., M. Pevzner, and C. Seethamraju (2010). The implications of absorption cost accounting and production decisions for future firm performance and valuation. Working Paper. Washington University.

Haw, I, K. Jung, , and S. Lilien (1991). Overfunded defined benefit pension plan settlements without asset reversion. Journal of Accounting and Economics 14, 295-320.

Healy, P. and K. Palepu (1990). Effectiveness of accounting-based dividend covenants. Journal of Accounting and Economics, 12(1), 97-123.

Holthausen, R., (1981). Evidence on the effect of bond covenants and management compensation contracts on the choice of accounting techniques. Journal of Accounting and Economics 3, 73-109. 
Jones, J. (1991). Earnings management during import relief investigations. Journal of Accounting Research, 29, 193-228.

Kim, B. (2009). Post-borrowing conservatism and debt covenant slack. Working Paper. American University.

Kothari, SP, A. Leone, and C. Wasley (2005). Performance-matched discretionary accruals measures. Journal of Accounting and Economics, 39,163-197.

Nini, G, D. Smith, and A.Sufi (2009). Creditor control rights and firms' investment policy. Journal of Financial Economics, 92(3), 400-420.

Nikolaev, V. (2010). Debt covenants and accounting conservatism. Journal of Accounting Research, 48(1), 137-175.

Roberts, M. and A. Sufi (2009a). Control rights and Capital Structure: An Empirical Investigation. Journal of Finance, 64, 1657-1695.

(2009b). Renegotiation of financial contracts: Evidence from private credit agreements. Journal of Financial Economics, 93,159-184.

Roychowdhury, S. (2006). Earnings management through real activities manipulation. Journal of Accounting and Economics, 42(3), 335-370.

Sweeney, A., (1994). Debt-covenant violations and managers' accounting responses. Journal of Accounting and Economics 17, 281-308.

Watts, R. and J. Zimmerman (1986). Positive Accounting Theory, Prentice Hall.

Zang, A. (2007). Evidence on the Tradeoff Between Real Manipulation and Accrual Manipulation. Working Paper. HKUST.

Zhang, X. (2007). Economic consequences of the Sarbanes-Oxley Act of 2002. Journal of Accounting and Economics, 44(1), 74-115.

Zhang, J. (2008). The contracting benefits of accounting conservatism to lenders and borrowers. Journal of Accounting and Economics, 45(1), $27-54$. 


\section{Appendix: Variables Definitions}

REM Real earnings management variables following Roychowdhury (2006):

ABN_CFO: Abnormal cash flows (negative measure of real earnings management)

ABN_Prod: Abnormal inventory over-production (positive measure of real earnings management)

ABN_Discexp: Abnormal discretionary expenses (negative measure of real earnings management)

REM_Index: ABN_Prod/std(ABN_Prod) - ABN_CFO/std(ABN_CFO) $A B N \_$Discexp/Std(ABN_Discexp) where $\operatorname{std}($.$) stands for standard$ deviation of each respective variable.

T_SLACK Tightness of debt covenant slack. We combine net worth and tangible net worth covenant slack into a single net worth covenant slack variable. For net worth covenant, the tightness of covenant slack is defined as the required minimum net worth covenant per DealScan minus actual common equity (CEQ), deflated by prior year's total assets. For tangible net worth covenant, the tightness of covenant slack is defined as the required minimum tangible net worth covenant per DealScan minus actual common equity less intangible assets, deflated by prior year's total assets. A larger (i.e., less negative) $T_{-} S L A C K$ indicates tighter covenant, i.e., closer to violation

LAT Natural $\log$ of total assets

MTB A firm's market-to-book ratio

LEV A firm's leverage defined as the ratio of total liabilities to assets

ROA A firm's return on assets defined as the ratio of earnings before extraordinary items deflated by prior period assets

$\triangle G D P \quad$ Change in annual level of US GDP as reported by the US Bureau of Economic Analysis

$D A$

Modified Jones (1991) model of discretionary accruals, with control for contemporaneous accounting performance as suggested in Kothari et al (2005). 
CLOSE A dummy variable equal to one if the magnitude of $T_{-} S L A C K$ is between 0 and $-10 \%$, and zero otherwise.

$\triangle B A N K \quad$ A dummy variable equal to one if a firm experiences an increase in estimated default frequency (Merton KMV Measure of bankruptcy risk, estimated using an algorithm in Bharath and Shumway (2008)) in the prior year.

Z_Score Altman Z-score

Log(Maturity) Natural logarithm of the remaining maturity of the loan in months obtained from Dealscan

N_Covenants Total number of covenants in a particular loan

$\log ($ Age $) \quad$ Natural logarithm of firm age

BTM A firm's book-to-market ratio

$\triangle L E V \quad$ Change in overall leverage

DIV_YIELD Dividend yield of a firm (ratio of total dividends paid to stock price)

TANGIBILITY Ratio of net fixed assets to total assets

$C L \quad$ Ratio of current liabilities to total assets

NCR Dummy variable equal 1 if a firm does not have a long-term credit rating in Compustat, and 0 otherwise

MFG dummy variable equal to 1 for manufacturing firms (SIC codes between 2000 and 3999), and 0 otherwise

NOA Level of a firm's net operating assets, deflated by prior year assets (used to control for earnings management constraint per Barton and Simko, 2002 and Cohen and Zarowin, 2009)

Log(Amount) Natual logarithm of the amount of the loan obtained from Dealscan

M_REM_Index $\quad$ Median levels of REM_Index

$M \_D A \quad$ Median levels of $D A$ 


\section{Table 1}

\section{Descriptive Statistics}

This Table summarizes descriptive statistics for variables defined in the Appendix.

\begin{tabular}{|c|c|c|c|c|c|c|}
\hline \multicolumn{7}{|c|}{ Panel A: Descriptive Statistics for H1, H1a, and H1b } \\
\hline & $\mathrm{N}$ & Mean & Std. Dev. & Q1 & Median & Q3 \\
\hline $\mathrm{ABN} \_\mathrm{CFO}_{\mathrm{t}}$ & 4249 & 0.024 & 0.109 & -0.03 & 0.026 & 0.084 \\
\hline ABN_Prod ${ }_{t}$ & 4249 & -0.001 & 0.207 & -0.118 & -0.014 & 0.093 \\
\hline ABN_Discexp $p_{t}$ & 4249 & -0.002 & 0.221 & -0.107 & -0.008 & 0.097 \\
\hline REM_Index & 4249 & 0.007 & 1.979 & -1.042 & -0.049 & 0.948 \\
\hline T-SLACK ${ }_{t}$ & 4249 & -0.214 & 0.198 & -0.279 & -0.159 & -0.082 \\
\hline $\mathrm{LAT}_{\mathrm{t}-1}$ & 4249 & 5.714 & 1.513 & 4.691 & 5.723 & 6.662 \\
\hline $\mathrm{MTB}_{\mathrm{t}-1}$ & 4249 & 2.336 & 2.23 & 1.165 & 1.815 & 2.766 \\
\hline $\mathrm{LEV}_{\mathrm{t}-1}$ & 4249 & 0.605 & 0.348 & 0.406 & 0.561 & 0.711 \\
\hline $\mathrm{ROA}_{\mathrm{t}-1}$ & 4249 & 0.049 & 0.105 & 0.016 & 0.054 & 0.092 \\
\hline$\Delta \mathrm{GDP}_{\mathrm{t}-1}$ & 4249 & 3.316 & 1.216 & 2.5 & 3.7 & 4.4 \\
\hline $\mathrm{DA}_{\mathrm{t}}$ & 4249 & -0.029 & 1.565 & -0.101 & -0.008 & 0.085 \\
\hline $\mathrm{CLOSE}_{\mathrm{t}}$ & 4249 & 0.309 & 0.462 & 0 & 0 & 1 \\
\hline$\Delta \mathrm{BANK}_{\mathrm{t}-1}$ & 3727 & 0.498 & 0.5 & 0 & 0 & 1 \\
\hline
\end{tabular}

\begin{tabular}{|c|c|c|c|c|c|c|}
\hline \multicolumn{7}{|c|}{ Panel B: Descriptive Statistics for H2 } \\
\hline & $\mathrm{N}$ & Mean & Std. Dev. & Q1 & Median & Q3 \\
\hline Future_viol ${ }_{t+1}$ & 2813 & 0.095 & 0.293 & 0 & 0 & 0 \\
\hline $\mathrm{DA}_{\mathrm{t}}$ & 2813 & -0.028 & 1.38 & -0.098 & -0.011 & 0.076 \\
\hline REM_Index $x_{t}$ & 2813 & 0.045 & 1.923 & -0.963 & -0.025 & 0.937 \\
\hline $\mathrm{LAT}_{\mathrm{t}}$ & 2813 & 5.927 & 1.41 & 4.981 & 5.914 & 6.849 \\
\hline $\operatorname{Lev}_{\mathrm{t}}$ & 2813 & 0.505 & 0.17 & 0.386 & 0.509 & 0.625 \\
\hline $\mathrm{ROA}_{\mathrm{t}}$ & 2813 & 0.052 & 0.081 & 0.017 & 0.052 & 0.088 \\
\hline Z-score $_{\mathrm{t}}$ & 2813 & 4.245 & 2.936 & 2.662 & 3.601 & 4.974 \\
\hline $\log (\text { Maturity })_{t}$ & 2813 & 3.851 & 0.475 & 3.611 & 3.989 & 4.111 \\
\hline $\mathrm{N}_{-}$Covenants $_{\mathrm{t}}$ & 2813 & 3.213 & 1.128 & 3 & 3 & 4 \\
\hline $\log (\text { Age })_{t}$ & 2813 & 2.602 & 0.798 & 1.946 & 2.639 & 3.296 \\
\hline
\end{tabular}


Table 2

Correlations

This Table summarizes the pair-wise Pearson correlations for variables defined in the Appendix. * denotes significance level of $10 \%$. Panel A: Pair-wise Pearson Correlations for Variables in testing $\mathrm{H} 1, \mathrm{H} 1 \mathrm{a}$, and $\mathrm{H} 1 \mathrm{~b}$

\begin{tabular}{|c|c|c|c|c|c|c|c|c|c|c|c|c|c|}
\hline & (1) & (2) & (3) & (4) & (5) & (6) & (7) & (8) & (9) & (10) & (11) & (12) & (13) \\
\hline \multirow[t]{2}{*}{ ABN_CFOt(1) } & 1 & & & & & & & & & & & & \\
\hline & 4249 & & & & & & & & & & & & \\
\hline \multirow[t]{2}{*}{ ABN_Prodt(2) } & $-0.3580^{*}$ & 1 & & & & & & & & & & & \\
\hline & 4249 & 4249 & & & & & & & & & & & \\
\hline \multirow[t]{2}{*}{ ABN_Discexpt(3) } & -0.0206 & $-0.7094^{*}$ & 1 & & & & & & & & & & \\
\hline & 4249 & 4249 & 4249 & & & & & & & & & & \\
\hline \multirow[t]{2}{*}{ REM_Indext(4) } & $-0.5856^{*}$ & $0.9088^{*}$ & $-0.7282^{*}$ & 1 & & & & & & & & & \\
\hline & 4249 & 4249 & 4249 & 4249 & & & & & & & & & \\
\hline \multirow[t]{2}{*}{ T_SLACK $(5)$} & $-0.1402^{*}$ & $0.0970^{*}$ & $-0.1367^{*}$ & $0.1634^{*}$ & 1 & & & & & & & & \\
\hline & 4249 & 4249 & 4249 & 4249 & 4249 & & & & & & & & \\
\hline \multirow[t]{2}{*}{$\mathrm{LAT}_{\mathrm{t}-1}(6)$} & $0.0923^{*}$ & -0.0091 & $-0.0913^{*}$ & -0.0057 & $0.0562^{*}$ & 1 & & & & & & & \\
\hline & 4249 & 4249 & 4249 & 4249 & 4249 & 4249 & & & & & & & \\
\hline \multirow[t]{2}{*}{$\operatorname{MTB}_{\mathrm{t}-1}(7)$} & $0.1199^{*}$ & $-0.1597^{*}$ & $0.1776^{*}$ & $-0.2110^{*}$ & $-0.2570^{*}$ & $0.0757^{*}$ & 1 & & & & & & \\
\hline & 4249 & 4249 & 4249 & 4249 & 4249 & 4249 & 4249 & & & & & & \\
\hline \multirow[t]{2}{*}{$\operatorname{LEV}_{\mathrm{t}-1}(8)$} & $-0.0949^{*}$ & $0.1016^{*}$ & $-0.0625^{*}$ & $0.1048^{*}$ & $0.1450^{*}$ & $0.1425^{\star}$ & $0.0926^{*}$ & 1 & & & & & \\
\hline & 4249 & 4249 & 4249 & 4249 & 4249 & 4249 & 4249 & 4249 & & & & & \\
\hline \multirow[t]{2}{*}{$\mathrm{ROA}_{\mathrm{t}-1}(9)$} & $0.2710^{*}$ & $-0.0490^{*}$ & $-0.1020^{*}$ & $-0.0988^{*}$ & $-0.1969^{*}$ & $0.1521^{*}$ & $0.1624^{*}$ & 0.015 & 1 & & & & \\
\hline & 4249 & 4249 & 4249 & 4249 & 4249 & 4249 & 4249 & 4249 & 4249 & & & & \\
\hline \multirow[t]{2}{*}{$\Delta \operatorname{GDP}_{\mathrm{t}-1}(10)$} & $-0.0261^{*}$ & -0.0002 & 0.0161 & -0.0009 & $0.0368^{*}$ & $-0.1171^{*}$ & $0.0363^{*}$ & $0.1168^{*}$ & -0.0011 & 1 & & & \\
\hline & 4249 & 4249 & 4249 & 4249 & 4249 & 4249 & 4249 & 4249 & 4249 & 4249 & & & \\
\hline \multirow[t]{2}{*}{$\mathrm{DA}_{\mathrm{t}}(11)$} & $-0.0451^{*}$ & -0.0003 & 0.0144 & 0.0146 & $0.0298^{*}$ & $-0.0275^{*}$ & $-0.0320^{*}$ & 0.0055 & $-0.0307^{*}$ & 0.0042 & 1 & & \\
\hline & 4249 & 4249 & 4249 & 4249 & 4249 & 4249 & 4249 & 4249 & 4249 & 4249 & 4249 & & \\
\hline \multirow[t]{2}{*}{$\operatorname{CLOSE}_{t}(12)$} & $-0.1375^{*}$ & $0.0453^{*}$ & -0.0251 & $0.0911^{*}$ & $0.5488^{*}$ & $-0.0535^{*}$ & $-0.1424^{*}$ & $0.1266^{*}$ & $-0.1998^{*}$ & $0.0519^{*}$ & $0.0322^{*}$ & 1 & \\
\hline & 4249 & 4249 & 4249 & 4249 & 4249 & 4249 & 4249 & 4249 & 4249 & 4249 & 4249 & 4249 & \\
\hline \multirow[t]{2}{*}{$\triangle$ BANK $_{\mathrm{t}-1}(13)$} & $-0.0478^{*}$ & 0.0166 & -0.0136 & $0.0385^{\star}$ & $0.1059^{*}$ & 0.0006 & $-0.1029^{*}$ & $0.1383^{*}$ & $-0.1282^{*}$ & $0.0498^{*}$ & -0.0187 & $0.0870^{*}$ & 1 \\
\hline & 3727 & 3727 & 3727 & 3727 & 3727 & 3727 & 3727 & 3727 & 3727 & 3727 & 3727 & 3727 & 3727 \\
\hline
\end{tabular}




\begin{tabular}{|c|c|c|c|c|c|c|c|c|c|c|}
\hline \multicolumn{11}{|c|}{ Panel B: Pair-wise Pearson Correlations for Variables in testing H2 } \\
\hline & (14) & $(15)$ & $(16)$ & $(17)$ & $(18)$ & $(19)$ & (20) & (21) & (22) & $(23)$ \\
\hline \multirow[t]{2}{*}{ Future_viol $+1+1$ (14) } & 1 & & & & & & & & & \\
\hline & 2813 & & & & & & & & & \\
\hline \multirow[t]{2}{*}{$\mathrm{DA}_{t}(15)$} & 0.0199 & 1 & & & & & & & & \\
\hline & 2813 & 2813 & & & & & & & & \\
\hline \multirow[t]{2}{*}{ REM_Indext $(16)$} & $0.0868^{*}$ & -0.0035 & 1 & & & & & & & \\
\hline & 2813 & 2813 & 2813 & & & & & & & \\
\hline \multirow[t]{2}{*}{$\operatorname{LAT}_{t}(17)$} & $-0.0745^{*}$ & 0.0182 & $-0.0483^{*}$ & 1 & & & & & & \\
\hline & 2813 & 2813 & 2813 & 2813 & & & & & & \\
\hline \multirow[t]{2}{*}{ Levt (18) } & $0.1251^{*}$ & 0.0154 & $0.2041^{*}$ & $0.1859^{*}$ & 1 & & & & & \\
\hline & 2813 & 2813 & 2813 & 2813 & 2813 & & & & & \\
\hline \multirow[t]{2}{*}{$\mathrm{ROA}_{t}(19)$} & $-0.2464^{*}$ & 0.0133 & $-0.2189^{*}$ & $0.1144^{*}$ & $-0.2092^{*}$ & 1 & & & & \\
\hline & 2813 & 2813 & 2813 & 2813 & 2813 & 2813 & & & & \\
\hline \multirow[t]{2}{*}{ Z-scoret $(20)$} & $-0.1325^{\star}$ & $-0.0539^{*}$ & $-0.1687^{*}$ & $-0.0382^{*}$ & $-0.5440^{*}$ & $0.4159^{*}$ & 1 & & & \\
\hline & 2813 & 2813 & 2813 & 2813 & 2813 & 2813 & 2813 & & & \\
\hline \multirow[t]{2}{*}{ Log(Maturity)t (21) } & $-0.0618^{*}$ & -0.0029 & -0.0169 & $0.1633^{*}$ & $0.0775^{*}$ & $0.0813^{*}$ & $-0.0482^{*}$ & 1 & & \\
\hline & 2813 & 2813 & 2813 & 2813 & 2813 & 2813 & 2813 & 2813 & & \\
\hline \multirow[t]{2}{*}{ N_Covenantst $(22)$} & $0.0433^{*}$ & 0.0046 & -0.0023 & $-0.1195^{*}$ & 0.0115 & 0.0098 & $-0.0560^{*}$ & $-0.0320^{*}$ & 1 & \\
\hline & 2813 & 2813 & 2813 & 2813 & 2813 & 2813 & 2813 & 2813 & 2813 & \\
\hline \multirow[t]{2}{*}{$\log (\text { Age })_{t}(23)$} & $-0.0664^{*}$ & 0.0031 & 0.013 & $0.2656^{*}$ & $0.0901^{*}$ & $0.0604^{*}$ & $-0.0911^{*}$ & $0.0702^{*}$ & $-0.0902^{*}$ & 1 \\
\hline & 2813 & 2813 & 2813 & 2813 & 2813 & 2813 & 2813 & 2813 & 2813 & 2813 \\
\hline
\end{tabular}




\section{Table 3}

\section{Regression Analysis}

This Table summarizes the regressions of real earnings management variables on the tightness of net worth/tangible net worth covenant slack and other control variables (Model 1). All continuous variables are winsorized at the $1^{\text {st }}$ and $99^{\text {th }}$ percentiles, respectively. All models include year fixed effects and the $t$-statistics in parentheses are based on the two-way cluster-robust standard errors (cluster by firm and by year), which adjust for both cross-sectional and time-series dependence in panel data. *,**, *** denote significance levels of $10 \%, 5 \%$, and $1 \%$, respectively. All variables are defined in the Appendix.

\begin{tabular}{lcccc}
\hline & REM_Index & ABN_CFO & ABN_Prod & ABN_Discexp \\
\hline Intercept & $1.226 * * *$ & $-0.070_{\mathrm{t}} * * *$ & $0.069 * * *$ & $-0.398^{* * *}$ \\
& $(6.23)$ & $(-5.91)$ & $(3.17)$ & $(-15.05)$ \\
T_SLACK & $0.927 * * *$ & $-0.034 * * *$ & $0.041 * *$ & $-0.121 * * *$ \\
& $(4.65)$ & $(-2.59)$ & $(2.24)$ & $(-4.55)$ \\
LAT $_{\mathrm{t}-1}$ & -0.021 & $0.005 * * *$ & -0.003 & $-0.009 * *$ \\
& $(-0.58)$ & $(3.28)$ & $(-0.86)$ & $(-2.17)$ \\
MTB $_{\mathrm{t}-1}$ & $-0.169 * * *$ & $0.003 * * *$ & $-0.015 * * *$ & $0.018^{* * *}$ \\
& $(-8.41)$ & $(3.33)$ & $(-7.90)$ & $(6.68)$ \\
LEV $_{\mathrm{t}-1}$ & $0.661 * * *$ & $-0.032 * * *$ & $0.071 * * *$ & $-0.037 * *$ \\
& $(5.21)$ & $(-5.62)$ & $(4.85)$ & $(-2.19)$ \\
ROA $_{\mathrm{t}-1}$ & $-1.002 * *$ & $0.248 * *$ & -0.038 & $-0.294 * * *$ \\
& $(-2.36)$ & $(7.04)$ & $(-0.93)$ & $(-5.17)$ \\
$\Delta$ GDP $_{\mathrm{t}-1}$ & -0.011 & 0.002 & -0.002 & 0.002 \\
& $(-0.29)$ & $(0.39)$ & $(-0.35)$ & $(0.17)$ \\
DA & 0.007 & $-0.002 * *$ & -0.001 & $0.002 *$ \\
& $(0.38)$ & $(-2.14)$ & $(-0.47)$ & $(1.69)$ \\
Year Dummies & Yes & Yes & Yes & Yes \\
& & & & 4249 \\
\hline$N$ & 4249 & 4249 & 4249 & 0.072 \\
\hline
\end{tabular}




\section{Table 4}

\section{Closeness to Net Worth Covenant Violation}

This Table summarizes the regressions of real earnings management variables on the tightness of net worth/tangible net worth covenant slack interacting with closeness to net worth covenant violation dummy variable and other control variables (Model 2). All continuous variables are winsorized at the $1^{\text {st }}$ and $99^{\text {th }}$ percentiles, respectively. All models include year fixed effects and the $t$-statistics in parentheses are based on the two-way cluster-robust standard errors (cluster by firm and by year), which adjust for both cross-sectional and time-series dependence in panel data. $*, * *, * * *$ denote significance levels of $10 \%, 5 \%$, and $1 \%$, respectively. All variables are defined in the Appendix.

\begin{tabular}{|c|c|c|c|c|}
\hline & REM_Index & $\mathrm{ABN}_{-} \mathrm{CFO}_{\mathrm{t}}$ & $\mathrm{ABN}_{\text {_Prod }}$ & $\mathrm{ABN}_{2}$ Discexp $\mathrm{t}$ \\
\hline \multirow[t]{2}{*}{ Intercept } & $1.229 * * *$ & $-0.066 * * *$ & $0.072 * * *$ & $-0.404 * * *$ \\
\hline & $(6.22)$ & $(-5.44)$ & $(3.22)$ & $(-15.14)$ \\
\hline \multirow[t]{2}{*}{ T_SLACK } & $0.952 * * *$ & -0.021 & $0.051 * *$ & $-0.145 * * *$ \\
\hline & $(3.85)$ & $(-1.37)$ & $(2.29)$ & $(-4.75)$ \\
\hline \multirow[t]{2}{*}{ T_SLACK ${ }_{\mathrm{t}} * \mathrm{CLOSE}_{\mathrm{t}}$} & $3.626^{*}$ & $-0.212 * *$ & 0.219 & $-0.436 * *$ \\
\hline & $(1.75)$ & $(-2.24)$ & $(0.87)$ & $(-2.03)$ \\
\hline \multirow[t]{2}{*}{$\mathrm{CLOSE}_{\mathrm{t}}$} & 0.152 & $-0.021 * * *$ & 0.003 & -0.001 \\
\hline & (1.02) & $(-3.44)$ & $(0.14)$ & $(-0.07)$ \\
\hline \multirow[t]{2}{*}{$\mathrm{LAT}_{\mathrm{t}-1}$} & -0.022 & $0.005 * * *$ & -0.003 & $-0.008 * *$ \\
\hline & $(-0.63)$ & (3.13) & $(-0.92)$ & $(-2.06)$ \\
\hline \multirow{2}{*}{$\mathrm{MTB}_{\mathrm{t}-1}$} & $-0.169 * * *$ & $0.003 * * *$ & $-0.015 * * *$ & $0.018 * * *$ \\
\hline & $(-8.49)$ & $(3.36)$ & $(-8.00)$ & $(6.70)$ \\
\hline \multirow[t]{2}{*}{$\mathrm{LEV}_{\mathrm{t}-1}$} & $0.661 * * *$ & $-0.031 * * *$ & $0.071 * * *$ & $-0.038 * *$ \\
\hline & $(5.24)$ & $(-5.46)$ & $(4.90)$ & $(-2.26)$ \\
\hline \multirow[t]{2}{*}{$\mathrm{ROA}_{\mathrm{t}-1}$} & $-0.983 * *$ & $0.243 * * *$ & -0.039 & $-0.290 * * *$ \\
\hline & $(-2.32)$ & $(6.87)$ & $(-0.97)$ & $(-5.09)$ \\
\hline \multirow[t]{2}{*}{$\Delta \mathrm{GDP}_{\mathrm{t}-1}$} & -0.006 & 0.001 & -0.001 & 0.001 \\
\hline & $(-0.17)$ & $(0.36)$ & $(-0.27)$ & $(0.09)$ \\
\hline \multirow[t]{2}{*}{$\mathrm{DA}_{\mathrm{t}}$} & 0.007 & $-0.002 * *$ & -0.001 & 0.002 \\
\hline & $(0.38)$ & $(-2.11)$ & $(-0.45)$ & $(1.60)$ \\
\hline Year Dummies & Yes & Yes & Yes & Yes \\
\hline$N$ & 4249 & 4249 & 4249 & 4249 \\
\hline Adj. $R^{2}$ & 0.072 & 0.102 & 0.041 & 0.074 \\
\hline
\end{tabular}




\section{Table 5}

\section{Closeness to Net Worth Covenant Violation and Increase in Bankruptcy Risk}

This Table summarizes the regressions of real earnings management variables on the three-way interaction term (the tightness of net worth/tangible net worth covenant slack, closeness to net worth covenant violation dummy variable, and increase in bankruptcy risk dummy) and other control variables (Model 3). All continuous variables are winsorized at the $1^{\text {st }}$ and $99^{\text {th }}$ percentiles, respectively. All models include year fixed effects and the $t$-statistics in parentheses are based on the two-way cluster-robust standard errors (cluster by firm and by year), which adjust for both cross-sectional and time-series dependence in panel data. *,**,*** denote significance levels of $10 \%, 5 \%$, and $1 \%$, respectively. All variables are defined in the Appendix.

\begin{tabular}{|c|c|c|c|c|}
\hline & REM_Index $_{t}$ & ABN_CFO & ABN_Prod $_{t}$ & ABN_Discexp \\
\hline \multirow[t]{2}{*}{ Intercept } & $1.248 * * *$ & $-0.067 * * *$ & $0.068 * * *$ & $-0.413 * * *$ \\
\hline & $(4.84)$ & $(-3.56)$ & $(2.59)$ & $(-11.74)$ \\
\hline \multirow[t]{2}{*}{ T_SLACK } & $1.294 * * *$ & $-0.043 *$ & $0.050 *$ & $-0.157 * * *$ \\
\hline & (3.28) & $(-1.89)$ & $(1.79)$ & $(-3.58)$ \\
\hline \multirow[t]{2}{*}{ T_SLACK ${ }_{t}^{*} \operatorname{CLOSE}_{t}$} & -0.918 & 0.041 & -0.334 & -0.343 \\
\hline & $(-0.25)$ & $(0.22)$ & $(-0.77)$ & $(-1.07)$ \\
\hline \multirow[t]{2}{*}{$\mathrm{T}_{-} \mathrm{SLACK}_{\mathrm{t}}{ }^{*} \mathrm{CLOSE}_{\mathrm{t}}{ }^{*} \Delta \mathrm{BANK}_{\mathrm{t}-1}$} & $9.343 * * *$ & $-0.529 * *$ & $1.013 * * *$ & -0.137 \\
\hline & $(2.67)$ & $(-2.35)$ & $(2.74)$ & $(-0.48)$ \\
\hline \multirow[t]{2}{*}{ CLOSE $_{t}$} & -0.125 & -0.004 & -0.026 & 0.002 \\
\hline & $(-0.50)$ & $(-0.32)$ & $(-0.95)$ & $(0.08)$ \\
\hline \multirow[t]{2}{*}{$\Delta \mathrm{BANK}_{\mathrm{t}-1}$} & -0.212 & $0.022 * * *$ & -0.000 & 0.001 \\
\hline & $(-1.64)$ & $(2.88)$ & $(-0.02)$ & $(0.07)$ \\
\hline \multirow{2}{*}{$\mathrm{T}_{-} \mathrm{SLACK}_{\mathrm{t}} * \triangle \mathrm{BANK} \mathrm{t}-1$} & $-0.885^{*}$ & $0.078 * * *$ & 0.007 & 0.030 \\
\hline & $(-1.90)$ & $(2.88)$ & $(0.18)$ & $(0.62)$ \\
\hline \multirow[t]{2}{*}{$\mathrm{CLOSE}_{\mathrm{t}} * \Delta \mathrm{BANK}_{\mathrm{t}-1}$} & $0.518 * *$ & $-0.038 * * *$ & $0.043^{*}$ & 0.001 \\
\hline & $(2.04)$ & $(-2.59)$ & $(1.80)$ & $(0.09)$ \\
\hline \multirow[t]{2}{*}{$\mathrm{LAT}_{\mathrm{t}-1}$} & -0.019 & $0.005 * *$ & -0.003 & $-0.008 *$ \\
\hline & $(-0.48)$ & $(2.53)$ & $(-0.83)$ & $(-1.68)$ \\
\hline \multirow[t]{2}{*}{$\mathrm{MTB}_{\mathrm{t}-1}$} & $-0.162 * * *$ & $0.004 * * *$ & $-0.014 * * *$ & $0.017 * * *$ \\
\hline & $(-6.89)$ & (3.17) & $(-6.49)$ & (6.14) \\
\hline \multirow[t]{2}{*}{$\mathrm{LEV}_{\mathrm{t}-1}$} & $0.682 * * *$ & $-0.037 * * *$ & $0.073 * * *$ & $-0.031 * *$ \\
\hline & $(4.35)$ & $(-4.41)$ & $(4.72)$ & $(-2.06)$ \\
\hline \multirow[t]{2}{*}{$\mathrm{ROA}_{\mathrm{t}-1}$} & -0.642 & $0.217 * * *$ & -0.027 & $-0.289 * * *$ \\
\hline & $(-1.12)$ & $(4.96)$ & $(-0.54)$ & $(-5.35)$ \\
\hline \multirow[t]{2}{*}{$\Delta \mathrm{GDP}_{\mathrm{t}-1}$} & -0.016 & 0.003 & -0.001 & 0.001 \\
\hline & $(-0.29)$ & $(0.49)$ & $(-0.22)$ & $(0.10)$ \\
\hline \multirow[t]{2}{*}{$\mathrm{DA}_{t}$} & 0.013 & $-0.002 *$ & -0.000 & 0.001 \\
\hline & $(0.52)$ & $(-1.80)$ & $(-0.20)$ & $(0.37)$ \\
\hline Year Dummies & Yes & Yes & Yes & Yes \\
\hline$N$ & 3727 & 3727 & 3727 & 3727 \\
\hline Adj. $R^{2}$ & 0.063 & 0.087 & 0.036 & 0.064 \\
\hline
\end{tabular}




\section{Table 6}

\section{Real Earnings Management and Future Debt Covenant Violations}

This Table summarizes the logit regression of future net worth debt covenant violations on real earnings management index variable and other control variables. All continuous variables are winsorized at the $1^{\text {st }}$ and $99^{\text {th }}$ percentiles, respectively. All models include year fixed effects and the $z$-statistics in parentheses are based on the two-way cluster-robust standard errors (cluster by firm and by year), which adjust for both cross-sectional and timeseries dependence in panel data. $*, * *, * * *$ denote significance levels of $10 \%$, 5\%, and $1 \%$, respectively. All variables are defined in the Appendix.

\begin{tabular}{|c|c|c|}
\hline & Future_viol $_{t+1}$ & Future_viol $_{t+1}$ \\
\hline \multirow[t]{2}{*}{ Intercept } & $-10.216^{* * *}$ & $-10.6 \overline{3} 3 * * *$ \\
\hline & $(-8.72)$ & $(-9.38)$ \\
\hline \multirow{2}{*}{$\mathrm{DA}_{\mathrm{t}}$} & $0.067^{*}$ & $0.065^{*}$ \\
\hline & $(1.70)$ & $(1.67)$ \\
\hline \multirow[t]{2}{*}{ REM_Index $x_{t}$} & & $0.089 * *$ \\
\hline & & $(2.06)$ \\
\hline \multirow[t]{2}{*}{$\mathrm{LAT}_{\mathrm{t}}$} & $-0.071 *$ & -0.063 \\
\hline & $(-1.71)$ & $(-1.55)$ \\
\hline \multirow[t]{2}{*}{$\operatorname{Lev}_{t}$} & $1.560 * * *$ & $1.341 * * *$ \\
\hline & $(2.90)$ & (2.67) \\
\hline \multirow[t]{2}{*}{$\mathrm{ROA}_{t}$} & $-7.424 * * *$ & $-7.242 * * *$ \\
\hline & $(-7.81)$ & $(-7.96)$ \\
\hline \multirow{2}{*}{ Z-score $_{\mathrm{t}}$} & $-0.091 * *$ & $-0.100 * *$ \\
\hline & $(-2.26)$ & $(-2.48)$ \\
\hline \multirow[t]{2}{*}{$\log (\text { Maturity })_{\mathrm{t}}$} & $-0.297 * * *$ & $-0.278 * * *$ \\
\hline & $(-3.91)$ & $(-3.35)$ \\
\hline \multirow[t]{2}{*}{$\mathrm{N}_{-}$Covenants $_{\mathrm{t}}$} & $0.171 * * *$ & $0.172 * * *$ \\
\hline & $(2.72)$ & $(2.78)$ \\
\hline \multirow[t]{2}{*}{$\log (\text { Age })_{t}$} & $-0.107 *$ & -0.101 \\
\hline & $(-1.75)$ & $(-1.62)$ \\
\hline Year Dummies & Yes & Yes \\
\hline$N$ & 2813 & 2813 \\
\hline Pseudo $R^{2}$ & 0.1248 & 0.1278 \\
\hline
\end{tabular}




\section{Table 7}

\section{Controlling for Endogeneity of T-Slack}

This Table summarizes the regressions of real earnings management variables on the tightness of net worth covenant slack and other control variables after controlling for the endogeneity of the tightness of net worth covenant slack. All continuous variables are winsorized at the $1^{\text {st }}$ and $99^{\text {th }}$ percentiles, respectively. $t$-statistics in parentheses are based on the two-way cluster-robust standard errors (cluster by firm and by year), which adjust for both crosssectional and time-series dependence in panel data. *, **, *** denote significance levels of $10 \%, 5 \%$, and $1 \%$, respectively. All variables are defined in the Appendix.

\begin{tabular}{|c|c|c|}
\hline \multicolumn{3}{|c|}{ Panel A: First Stage Model: Predicting $T_{-} S L A C K_{t}$} \\
\hline & Coefficient & $t$ \\
\hline Intercept & $-0.400 * * *$ & -7.10 \\
\hline $\mathrm{LAT}_{\mathrm{t}-1}$ & $-0.013 * * *$ & -3.52 \\
\hline $\mathrm{BTM}_{\mathrm{t}-1}$ & $0.030 * * *$ & 8.51 \\
\hline $\mathrm{LEV}_{\mathrm{t}-1}$ & $0.113 * * *$ & 5.90 \\
\hline $\mathrm{ROA}_{\mathrm{t}-1}$ & -0.037 & -1.13 \\
\hline $\operatorname{Loss}_{t}$ & $0.054 * * *$ & 6.91 \\
\hline$\Delta \mathrm{LEV}_{\mathrm{t}-1}$ & -0.033 & -1.47 \\
\hline DIV YIELD $\mathrm{t}_{\mathrm{t}-1}$ & $0.005 * * *$ & 2.66 \\
\hline TANGIBILITY $_{\mathrm{t}-1}$ & $-0.048 * * *$ & -4.18 \\
\hline Z-Score $_{\mathrm{t}-1}$ & $-0.018 * * *$ & -14.96 \\
\hline $\mathrm{CL}_{\mathrm{t}}$ & $-0.064 * * *$ & -2.83 \\
\hline $\log (\text { Maturity })_{\mathrm{t}}$ & $-0.030 * * *$ & -5.40 \\
\hline $\mathrm{NCR}_{\mathrm{t}}$ & 0.006 & 0.95 \\
\hline $\mathrm{MFG}_{\mathrm{t}}$ & 0.005 & 0.83 \\
\hline $\mathrm{N}_{\text {_C Covenants }} \mathrm{C}$ & 0.002 & 0.68 \\
\hline $\log (\text { Amount })_{t}$ & $0.024 * * *$ & 6.15 \\
\hline $\mathrm{NOA}_{\mathrm{t}-1}$ & $-0.058 * * *$ & -4.19 \\
\hline$N$ & 4110 & \\
\hline $\operatorname{Adj} . R^{2}$ & 0.193 & \\
\hline
\end{tabular}




\begin{tabular}{|c|c|c|c|c|}
\hline \multicolumn{5}{|c|}{ Panel B: Second Stage Model (1) } \\
\hline & REM_Index ${ }_{t}$ & ABN_CFO & ABN_Prod ${ }_{t}$ & ABN_Discexp $p_{t}$ \\
\hline \multirow[t]{2}{*}{ Intercept } & $1.123 * * *$ & $-0.062 * * *$ & $0.064 * * *$ & $-0.388 * * *$ \\
\hline & $(5.83)$ & $(-5.03)$ & $(2.94)$ & $(-15.82)$ \\
\hline \multirow[t]{2}{*}{ ABN_T_SLACK } & $0.432 * *$ & -0.013 & 0.012 & $-0.060 * *$ \\
\hline & $(2.38)$ & $(-1.10)$ & $(0.62)$ & $(-2.14)$ \\
\hline \multirow[t]{2}{*}{$\mathrm{LMVE}_{\mathrm{t}-1}$} & -0.034 & $0.006 * * *$ & -0.003 & -0.007 \\
\hline & $(-0.92)$ & $(3.73)$ & $(-0.69)$ & $(-1.55)$ \\
\hline \multirow[t]{2}{*}{$\mathrm{MTB}_{\mathrm{t}-1}$} & $-0.190 * * *$ & $0.004 * * *$ & $-0.016 * * *$ & $0.021 * * *$ \\
\hline & $(-8.99)$ & $(3.38)$ & $(-8.33)$ & $(7.60)$ \\
\hline \multirow[t]{2}{*}{$\mathrm{LEV}_{\mathrm{t}-1}$} & $0.796 * * *$ & $-0.037 * * *$ & $0.076 * * *$ & $-0.054 * * *$ \\
\hline & $(5.53)$ & $(-6.67)$ & $(4.85)$ & $(-2.93)$ \\
\hline \multirow[t]{2}{*}{$\mathrm{ROA}_{\mathrm{t}-1}$} & $-1.374 * * *$ & $0.259 * * *$ & -0.051 & $-0.239 * * *$ \\
\hline & $(-3.01)$ & $(7.26)$ & $(-1.10)$ & $(-4.09)$ \\
\hline \multirow[t]{2}{*}{$\Delta \mathrm{GDP}_{\mathrm{t}-1}$} & -0.008 & -0.000 & -0.004 & 0.001 \\
\hline & $(-0.21)$ & $(-0.04)$ & $(-0.84)$ & $(0.17)$ \\
\hline \multirow[t]{2}{*}{$\mathrm{ABSDA}_{\mathrm{t}}$} & 0.008 & $-0.002 * *$ & -0.001 & 0.002 \\
\hline & $(0.41)$ & $(-2.09)$ & $(-0.52)$ & $(1.46)$ \\
\hline Year Dummies & Yes & Yes & Yes & Yes \\
\hline$N$ & 4114 & 4114 & 4114 & 4114 \\
\hline Adj. $R^{2}$ & 0.065 & 0.095 & 0.042 & 0.066 \\
\hline
\end{tabular}


Table 8

\section{Partition by Performance}

This Table summarizes the regressions of REM_Index on the tightness of net worth/tangible net worth covenant slack and other control variables (Model 1), partitioned by various performance measures. All continuous variables are winsorized at the $1^{\text {st }}$ and $99^{\text {th }}$ percentiles, respectively. All models include year fixed effects and the $t$-statistics in parentheses are based on the two-way cluster-robust standard errors (cluster by firm and by year), which adjust for both crosssectional and time-series dependence in panel data. *,**, *** denote significance levels of $10 \%, 5 \%$, and $1 \%$, respectively. All variables are defined in the Appendix.

\begin{tabular}{|c|c|c|c|c|c|c|c|c|}
\hline & $\mathrm{ROA}$ & $\mathrm{ROA}$ & & & Earnings & Earnings & $\begin{array}{l}\text { Altman } \\
\text { Z_score }\end{array}$ & $\begin{array}{l}\text { Altman } \\
\text { Z_score }\end{array}$ \\
\hline & Low & High & Loss $=1$ & Loss $=0$ & Decrease & Increase & Increase & Decrease \\
\hline \multirow[t]{2}{*}{ Intercept } & $1.868^{* \circledast 2}$ & $1.439^{* * *}$ & $2.025^{* \cdots *}$ & $1.303^{* * *}$ & $4.346^{* * *}$ & 0.460 & $1.567^{* \% *}$ & $2.889^{* * *}$ \\
\hline & $(5.60)$ & $(5.52)$ & $(4.32)$ & $(6.07)$ & $(8.83)$ & $(0.99)$ & $(5.50)$ & (13.77) \\
\hline \multirow{2}{*}{$\mathrm{T}_{-} \mathrm{SLACK}_{\mathrm{t}}$} & $1.035^{* * *}$ & $0.571^{* *}$ & $1.077^{* *}$ & $0.682^{* * *}$ & $1.251^{* * *}$ & $1.055^{* *}$ & $0.821^{* *}$ & $1.031^{* * *}$ \\
\hline & $(4.10)$ & (1.97) & $(2.33)$ & (3.12) & $(2.75)$ & $(2.39)$ & $(2.28)$ & $(2.71)$ \\
\hline \multirow[t]{2}{*}{$\mathrm{LMVE}_{\mathrm{t}-1}$} & -0.045 & -0.041 & -0.080 & -0.031 & -0.063 & -0.093 & $-0.097^{*}$ & -0.016 \\
\hline & $(-0.88)$ & $(-0.83)$ & $(-1.28)$ & $(-0.79)$ & $(-0.94)$ & $(-1.50)$ & $(-1.69)$ & $(-0.44)$ \\
\hline \multirow[t]{2}{*}{$\mathrm{MTB}_{\mathrm{t}-1}$} & $-0.102^{* * *}$ & $-0.180^{* * *}$ & $-0.106^{* * *}$ & $-0.162^{* * *}$ & $-0.229^{* * *}$ & $-0.204^{* * *}$ & $-0.222^{* * *}$ & $-0.238^{* * *}$ \\
\hline & $(-4.40)$ & $(-9.08)$ & $(-2.62)$ & $(-9.43)$ & $(-3.66)$ & $(-4.75)$ & $(-5.63)$ & $(-5.22)$ \\
\hline \multirow[t]{2}{*}{$\mathrm{LEV}_{\mathrm{t}-1}$} & $0.592^{* * *}$ & $0.765^{* * *}$ & $0.553^{* *}$ & $0.708^{* * *}$ & 0.504 & $0.783^{* *}$ & $1.482^{* * *}$ & $0.319^{* *}$ \\
\hline & $(4.59)$ & $(3.93)$ & $(2.53)$ & $(4.28)$ & $(1.45)$ & $(2.47)$ & (3.98) & $(2.54)$ \\
\hline \multirow[t]{2}{*}{$\mathrm{ROA}_{\mathrm{t}-1}$} & 0.625 & $-3.474^{* * *}$ & 0.814 & $-3.250^{* * *}$ & $-1.851^{*}$ & -1.686 & -0.136 & $-2.266^{*}$ \\
\hline & $(0.64)$ & $(-3.42)$ & $(0.56)$ & $(-4.49)$ & $(-1.72)$ & $(-1.45)$ & $(-0.16)$ & $(-1.86)$ \\
\hline \multirow[t]{2}{*}{$\Delta \mathrm{GDP}_{\mathrm{t}-1}$} & -0.015 & -0.032 & -0.156 & 0.013 & 0.031 & 0.048 & $-0.124^{*}$ & $0.150^{* *}$ \\
\hline & $(-0.20)$ & $(-0.67)$ & $(-0.82)$ & $(0.37)$ & $(0.28)$ & $(0.59)$ & $(-1.72)$ & $(2.31)$ \\
\hline \multirow[t]{2}{*}{$\mathrm{DA}_{\mathrm{t}}$} & 0.001 & 0.018 & 0.009 & 0.009 & -0.022 & 0.029 & 0.006 & 0.016 \\
\hline & $(0.04)$ & $(0.99)$ & $(0.39)$ & $(0.39)$ & $(-0.91)$ & $(0.74)$ & $(0.18)$ & $(0.52)$ \\
\hline Year Dummies & Yes & Yes & Yes & Yes & Yes & Yes & Yes & Yes \\
\hline$N$ & 2139 & 2110 & 708 & 3541 & 615 & 1062 & 1328 & 1241 \\
\hline Adj. $R^{2}$ & 0.033 & 0.090 & 0.038 & 0.082 & 0.077 & 0.098 & 0.101 & 0.091 \\
\hline
\end{tabular}




\section{Table 9}

\section{Simultaneous Models of Real and Accrual Earnings Management}

This Table summarizes the simultaneous regressions of real and accrual earnings management variables on the tightness of net worth covenant slack and other control variables. The simultaneous equations are estimated using the 3SLS technique. All continuous variables are winsorized at the $1^{\text {st }}$ and $99^{\text {th }}$ percentiles, respectively. *, **, *** denote significance levels of $10 \%, 5 \%$, and $1 \%$, respectively. All variables are defined in the Appendix.

\begin{tabular}{|c|c|c|}
\hline \multicolumn{3}{|c|}{ Panel A: Real Earnings Management Regressions } \\
\hline & REM_Index $_{t}$ & REM_Index \\
\hline \multirow[t]{2}{*}{ Intercept } & 0.392 & 0.392 \\
\hline & $(0.35)$ & $(0.21)$ \\
\hline \multirow{2}{*}{ T_SLACK ${ }_{t}$} & $1.596 * * *$ & $0.856^{* * * *}$ \\
\hline & $(10.44)$ & $(5.42)$ \\
\hline \multirow[t]{2}{*}{$\mathrm{DA}_{\mathrm{t}}$} & 0.008 & -0.005 \\
\hline & $(0.07)$ & $(-0.05)$ \\
\hline \multirow[t]{2}{*}{ M_REM_Index ${ }_{t}$} & $0.869 * * *$ & $0.890 * * *$ \\
\hline & $(8.63)$ & $(9.06)$ \\
\hline \multirow[t]{2}{*}{$\mathrm{LAT}_{\mathrm{t}-1}$} & & -0.030 \\
\hline & & $(-1.45)$ \\
\hline \multirow[t]{2}{*}{$\mathrm{MTB}_{\mathrm{t}-1}$} & & $-0.172 * * *$ \\
\hline & & $(-12.48)$ \\
\hline \multirow[t]{2}{*}{$\mathrm{LEV}_{\mathrm{t}-1}$} & & $0.734 * * *$ \\
\hline & & $(8.28)$ \\
\hline \multirow[t]{2}{*}{$\mathrm{ROA}_{\mathrm{t}-1}$} & & $-0.939 * * *$ \\
\hline & & $(-3.25)$ \\
\hline Year Dummies & Yes & Yes \\
\hline $\mathrm{N}$ & 4249 & 4247 \\
\hline $\mathrm{R}^{2}$ & 0.0477 & 0.0960 \\
\hline
\end{tabular}




\begin{tabular}{|c|c|c|}
\hline \multicolumn{3}{|c|}{ Panel B: Accrual Earnings Management Regressions } \\
\hline & $\mathrm{DA}_{\mathrm{t}}$ & $\mathrm{DA}_{\mathrm{t}}$ \\
\hline \multirow[t]{2}{*}{ Intercept } & 0.009 & 0.194 \\
\hline & $(0.01)$ & $(0.13)$ \\
\hline \multirow[t]{2}{*}{ T_SLACK } & 0.210 & 0.162 \\
\hline & $(1.07)$ & $(1.06)$ \\
\hline \multirow[t]{2}{*}{ REM_Index ${ }_{t}$} & 0.016 & 0.020 \\
\hline & $(0.17)$ & $(0.22)$ \\
\hline \multirow[t]{2}{*}{ M_DAt } & $0.821 * * *$ & $0.826 * * *$ \\
\hline & $(11.80)$ & $(11.86)$ \\
\hline \multirow[t]{2}{*}{$\mathrm{LAT}_{\mathrm{t}-1}$} & & $-0.030 *$ \\
\hline & & $(-1.79)$ \\
\hline \multirow[t]{2}{*}{$\mathrm{MTB}_{\mathrm{t}-1}$} & & -0.011 \\
\hline & & $(-0.57)$ \\
\hline \multirow[t]{2}{*}{$\mathrm{LEV}_{\mathrm{t}-1}$} & & 0.009 \\
\hline & & $(0.10)$ \\
\hline \multirow[t]{2}{*}{$\mathrm{ROA}_{\mathrm{t}-1}$} & & -0.231 \\
\hline & & $(-0.92)$ \\
\hline Year Dummies & Yes & Yes \\
\hline$N$ & 4249 & 4247 \\
\hline$R^{2}$ & 0.0381 & 0.0394 \\
\hline
\end{tabular}

